\title{
COVID-19 Pandemisi'nin Tekstil, Deri ve Giyim Eşyası Sektörlerinde Faaliyet Gösteren Firmalara ve Finansal Raporlarına Etkileri: BIST’te Bir Araştırma*
}

\section{Effects of COVID-19 Pandemic on Textile, Leather and Clothing Companies and Their Financial Reports: a Research in BIST}

\author{
Tuba Ergün ${ }^{1} \oplus$, Derya Üçoğlu ${ }^{2}$ \\ 'İstanbul Bilgi Üniversitesi, Lisansüstü Programlar Enstitüsü, Muhasebe ve Denetim Tezli Yüksek Lisans Programı, İstanbul, Türkiye \\ E-posta: tubaergn@gmail.com \\ ${ }^{2}$ Dr. Öğr. Üyesi, İstanbul Bilgi Üniversitesi, İşletme Fakültesi, İşletme Bölümü, İstanbul, Türkiye \\ E-posta: derya.ucoglu@bilgi.edu.tr \\ ORCID: T.E. 0000-0001-9779-7324; D.Ü 0000-0001-5510-3574
}

*Bu çalışma, Tuba Ergün'ün “COVID-19’un Otomotiv, Perakende Gıda, Ulaştırma ve Depolama, Tekstil, Deri ve Giyim Eşyası Sektörlerinde Faaliyet Gösteren Firmaların Finansal Tablolarına Etkileri: BİST’te Bir Araștırma" başlıklı yüksek lisans tezinden yararlanılarak üretilmiștir.

\section{Öz}

COVID-19 pandemisi, global ekonomik krize dönüşen bir sağlık krizidir. Bu çalışmanın amacı da COVID-19 pandemisinin tekstil, deri ve giyim eşyası sektörlerinde faaliyet gösteren işletmelere ve finansal raporlarına etkilerinin belirlenmesidir. Bu amaçla BİST’te listelenen ve tekstil, deri ve giyim eşyası sektörlerinde faaliyet gösteren 21 işletmenin 2019 ve 2020 yıl sonu finansal tabloları ve dipnotları kullanılarak yatay analiz, rasyo analizi ve içerik analizi yapılmıştır. Çalışma sonuçlarına göre pandemi döneminde işletmelerin yabancı kaynak kullanımının arttı̆̆ı, böylece pandeminin belirsizliklerine karşı işletmelerin 2019 yılından daha likit oldukları tespit edilmiştir. Pandemiyle birlikte hazır giyim, ayakkabı ve çanta üreten veya perakende satışını yapan firmaların hasılatlarında azalış, iplik, boyalı kumaş, astar gibi hazır giyim hammaddelerini üretip satan firmaların hasılatlarında artış görülmüştür. Hasılatlardaki azalış, finansman giderlerindeki artış ve kur farkı giderleri nedeniyle bu çalışmaya dahil edilmiş olan işletmelerin yarısının kârlılığında düşüş yaşanmıştır. İşletmelerin nakit yönetim stratejilerini gözden geçirmeleri ve aldıkları tedbirler kapsamında, iki işletme dışında 2020 yılında negatif net nakit akışına sahip işletme bulunmamaktadır. Genel olarak değerlendirildiğinde, tekstil, deri ve giyim eşyası sektörlerinde faaliyet gösteren halka açık işletmelerin pandemi sürecini iyi yönettikleri ve birkaç işletme dışında likidite ve kârlılıkla ilgili olarak önemli sorunlar yaşanmadığı görülmüştür. Dipnot açıklamalarıyla ilgili yapılan analiz ise işletmelerin bir kısmının COVID-19'la ilgili hiç açıklama yapmadıklarını, bir kısmının da sınırlı sayıda açıklama yaptıklarını ortaya koymuştur.

Anahtar kelimeler: COVID-19 Pandemisi, Tekstil Sektörü, Deri ve Giyim Eşyası, Finansal Etki, Borsa İstanbul (BİST)

Başvuru/Submitted: 22.09.2021 Revizyon Talebi/Revision Requested: 12.11.2021 Son Revizyon/Last Revision Received: 12.11 .2021 Kabul/Accepted: 27.12.2021 Sorumlu yazar/Corresponding author: Derya Üçoğlu / derya.ucoglu@bilgi.edu.tr 


\section{ABSTRACT}

The novel coronavirus disease 2019 (COVID-19) is a health concern that has rapidly turned into a global economic crisis. This study aims to determine the effects of the COVID-19 on textile, leather, and clothing companies and their financial reports. For this purpose, horizontal, ratio, and content analyses were carried out using the financial statements and footnotes of 21 companies listed in the BIST that fall under the aforementioned sectors. The results show that most of the companies have increased their liabilities during the pandemic and thus, considering such uncertainties in 2020 , possess more liquidity compared to the previous year. Revenues of retailing ready-made clothing, shoes, and bags were found to decrease, while those of clothing raw materials such as yarn, dyed fabric, and lining indicated an increase. Due to the pandemic, there has been a decrease in the revenues of companies producing or retailing ready-made clothing, shoes, and bags. In contrast, companies providing raw materials such as yarn, dyed fabric, and lining indicated an increase. Findings show reduced profitability in half of the examined companies due to decreased revenues, increased financial expenses, and foreign exchange losses. The companies reviewed their cash management strategies and enacted necessary measures. Therefore, except for two businesses, no other companies generated negative net cash flows in 2020. In summary, publicly traded textile, leather, and clothing companies were managed well during the pandemic. Apart from a few enterprises, no significant liquidity and profitability problems were encountered. Based on the analysis of the notes to the financial statements, several companies did not disclose any explanations regarding COVID-19, while others only reported limited disclosures.
\end{abstract}

Keywords: COVID-19 Pandemic, Textile Sector, Leather and Clothing, Financial Effect, Borsa Istanbul (BIST)

JEL Classification: M40, M41

\title{
Extended Abstract
}

The first coronavirus disease (COVID-19) case was reported in Wuhan in December 2019, and subsequently, the World Health Organization declared COVID-19 a pandemic in March 2020. It has taken a dramatic toll on human lives and global economies within a short period. Although several sectors did not experience any immediate consequences related to the crisis, most companies are expected to face significant losses in the long term (Üçoğlu, 2021:45).

The COVID-19 pandemic and the necessary protective measures have led to a decline in economic activities. Therefore, countries around the globe are currently trying to find ways to stabilize their economies (Kaur, 2021:1-2).

In Turkey, the ready-made clothing sector is one of the leading industries contributing to production and employment. Globally, as of 2019, Turkey is the 7th largest ready-made clothing exporter with a share of 3.3\% and ranks $3 \mathrm{rd}$ as the leading exporter to countries in the European Union (Hazır Giyim Sektör Raporu, 2020:1). Additionally, the textile sector has the highest foreign trade surplus and contributes to over 10\% of the country's gross domestic product (Uyanık and Çelikel, 2019:33). Following the food sector, the textile sector ranks second in production capacity (Uyanık and Çelikel, 2019:40).

As the economic consequences of COVID-19 continue, further research was carried out to identify its effects on global financial markets. However, the existing literature focuses mainly on changes in stock prices and stock market volatility, while industry-specific effects on company performance are seldom investigated (Cho and Saki, 2021:2).

Therefore, this study examines the effects of the COVID-19 pandemic on publicly traded companies operating in the textile, leather, and clothing sectors and their financial reports. Horizontal, ratio and, content analyses were carried out using the financial statements and footnote disclosures from 21 Borsa Istanbul (BIST) listed companies.

The analyses showed an increase in the companies' current and fixed assets during the first year of the pandemic. The increase in current assets, especially in cash and cash equivalents, was caused by the efforts to improve liquidity by reviewing cash management strategies. At the same time, those in trade receivables and inventories were related to reduced economic activity. Fixed assets increased mainly because of revaluations rather than capital expenditure investments.

Short-term and long-term liabilities of the majority of companies have increased. Given the intense uncertainty created by the pandemic, companies preferring high liquidity have increased their borrowing levels. Along with the increase in borrowings, the financial risks of companies such as Birlik Mensucat also increased.

In 2020, most sample companies reported a decline in their revenues. The few companies that incurred an increase in revenues generally produce carpets, home textiles, beds, quilts, armchairs, and sofas rather than ready-made clothing or raw materials such as yarn, dyed fabric, and lining. During the pandemic, disruptions in the supply chain, especially in importing raw materials, positively affected Turkish companies producing textile raw materials. 
Approximately half of the companies with lower revenues have increased their net profit margins. However, the profitability increase is not directly related to the pandemic but instead caused mainly by items reported under other operating income heading, such as fair value and foreign exchange gains.

The companies with negative cash flows from operating activities increased from four in 2019 to seven in 2020 . Due to precautionary measures, only two companies showed negative total cash flows from operating, investing, and financing activities in 2020. Therefore, the sector can be deemed successful in managing liquidity and cash flow adequacy during the pandemic.

When the effects of COVID-19 on the notes to the financial statements are examined, only very few footnote disclosures in Turkish companies regarding COVID-19 compared to the publicly traded companies in the United Kingdom and the United States are observed. While six Turkish companies did not make any disclosures concerning COVID-19, other companies reported a limited number of footnotes on the risks caused by the pandemic, the measures taken, government incentives received, and the impairment of assets.

In general, publicly held companies in the textile, leather, and clothing sectors highlighted good management strategies during the pandemic. Except for a few companies, no significant problems were associated with liquidity and profitability. However, given the high uncertainty caused by COVID-19, the companies increased their borrowings to improve liquidity. High levels of debt financing have created higher financial risks, and thus, the companies' long-term financial performance and position require close observation. 


\section{Giriş}

Aralık 2019'da Wuhan'da ilk koronavirüs vakasının bildirilmesinden sonra, Dünya Sağlık Örgütü (WHO), COVID-19'u Mart 2020'de pandemi olarak ilan etmiştir. COVID-19 pandemisi kısa sürede dramatik sayılarda insan yaşamına ve küresel ekonomik kayıplara neden olmuştur. Bazı şirketler veya sektörler krizin ani sonuçlarını yaşamamış olsa da çoğu şirketin uzun vadede önemli kayıplarla karşı karşıya kalması beklenmektedir (Üçoğlu, 2021:45).

COVID-19 pandemisinin etkileri, 2008 y1lında yaşanan mali kriz gibi diğer küresel krizlerin etkilerinden farkl1lık göstermektedir (Szczygielski vd., 2021: 3). Bunun en önemli nedenleri COVID-19'un küresel bir salgın olması ve virüsün bütün ülkelere yayılması, küresel finansal piyasaların birbirine son derece bağlı olması ve birbirlerini yoğun şekilde etkilemeleri, COVID-19'un arz ve talep şokları yaratması ve tedarik zincirleri boyunca her ülkeye yayılmasıdır (Ozili ve Arun, 2020).

Pandeminin kendisi kadar, alınan korunma tedbirleri de ekonomik aktivitelerin azalmasına sebep olmuştur. Bu nedenle, dünyanın dört bir yanındaki ülkeler şu anda ekonomilerini istikrara kavuşturmak için sorunlarla baş etmeye çalışmaktadır (Kaur, 2021:1-2).

Türkiye'de de pandeminin etkilerini azaltmak için sokağa çıkma yasakları, seyahat kısıtlamaları gibi kamu sağlığının korunması için alınan önlemlerin yanı sıra, piyasaları desteklemek için kısa çalışma ödeneği, işten çıkarma yasağı, nakdi ücret desteği, normalleşme desteği, ilave istihdam teşviği, KDV indirimi ve Kredi Garanti Fonu destekli krediler gibi destekler sağlanmıştır. Ancak gerek ülkemizde gerekse de tüm dünyada alınan tedbirler ve önlemler ne salgının bütünüyle hafiflemesini sağlamış ne de salgının finansal ve ekonomik etkilerini tamamen bertaraf etmiş̧tir.

$\mathrm{Bu}$ çalışmada COVID-19 pandemisinin Türkiye'nin önde gelen sektörlerinden biri olan tekstil, deri ve giyim eşyası sektörlerinde faaliyet gösteren halka açık işletmelere ve finansal raporlarına etkileri incelenmiştir. Öncelikle sektörün Türkiye için önemi ve pandeminin sektöre genel etkileri ele alınmıştır. Daha sonra tekstil, deri ve giyim eşyası sektörlerine pandeminin etkileri konusunda literatürde yapılmış çalışmalar özetlenmiştir. Son olarak da çalışma kapsamına dahil edilmiş olan 21 işletmenin finansal tabloları ve dipnot açıklamaları kullanılarak yatay analiz, rasyo analizi ve içerik analizi yapılmış, yapılan değerlendirmeler özetlenerek sunulmuştur.

\section{Tekstil, Deri ve Giyim Eşyası Sektörleri}

\subsection{Tekstil, Deri ve Giyim Eşyası Sektörlerinin Türkiye için Önemi}

Hazır giyim sektörü, üretim ve istihdamdaki katkılarıyla Türkiye'nin önde gelen sektörlerinden biri konumundadır. 2019 yılı itibariyle \%3,3’lük payılla, dünyanın 7. büyük hazır giyim ihracatçısı olan Türkiye, Avrupa Birliği (AB) ülkelerine hazır giyim ihracatında da 3. sırada yer almaktadır. Sektörde çoğunlukla küçük ve orta büyüklükte işletmeler faaliyet göstermekte olup, Sosyal Güvenlik Kurumu’nun 2020 yılı Ocak-Nisan dönemi istatistiklerine göre, giyim eşyaları imalatı, tekstil ve deri sektöründe yer alan firma sayısı 58.000 civarındadır. Söz konusu firmalarda istihdam edilen kişi sayısı da yaklaşık olarak 1.100.000'dir (Hazır Giyim Sektör Raporu, 2020:1). Ayrıca tekstil sektörü en fazla dış ticaret fazlası veren sektör olup, Türkiye'nin Gayrisafi Yurt İçi Hasıla’sının (GSYH) \%10’undan fazlasını sağlamaktadır (Uyanık ve Çelikel, 2019:33). İmalat sanayii dikkate alındığında, üretim kapasitesi bakımından gıda sektörünün ardından gelen sektör tekstil sektörüdür (Uyanık ve Çelikel, 2019:40).

İstanbul Sanayi Odası tarafından açıklanan, 2020 yılında Türkiye'nin 500 Büyük Sanayi Kuruluşu verilerine göre en büyük 500 sanayi şirketinin içinde tekstil ürünleri imalatı yapan 41 firma, giyim eşyalarının imalatını yapan 13 firma ve deri ve ilgili ürünlerin imalatını yapan 1 firma olmak üzere söz konusu alanlarda faaliyet gösteren toplam 55 firma bulunmaktadır. Firmaların bağlı bulundukları sanayi odaları ve toplam satış tutarları Tablo 1'de yer almaktadır (https://www.iso500.org. $\operatorname{tr} / 500$-buyuk-sanayi-kurulusu/2020/?ara=\&sektor_tipi=NACE\&sektor_kodu=15\&oda=\&calisan_sayisi $=\&$ sermaye yapisi=). 


\begin{tabular}{|c|c|c|}
\hline Firmaların Bağlı Bulunduğu Odalar & Firma Sayısı & Üretimden Toplam Satışlar (NET) (TL) \\
\hline Adana Sanayi Odası & 3 & 2.830 .213 .872 \\
\hline Ankara Sanayi Odası & 1 & 729.988 .339 \\
\hline Balıkesir Sanayi Odası & 1 & 594.135 .132 \\
\hline Bursa Ticaret ve Sanayi Odas1 & 3 & 2.677 .385 .167 \\
\hline Denizli Sanayi Odası & 2 & 1.995 .810 .913 \\
\hline Ege Bölgesi Sanayi Odası & 5 & 4.401 .690 .618 \\
\hline Gaziantep Sanayi Odası & 16 & 16.864 .333 .235 \\
\hline İnegöl Ticaret ve Sanayi Odası & 1 & 1.000 .635 .677 \\
\hline İstanbul Sanayi Odası & 12 & 9.210 .630 .011 \\
\hline Kahramanmaraş Ticaret ve Sanayi Odası & 6 & 6.600 .473 .912 \\
\hline Kayseri Sanayi Odası & 2 & 1.673 .609 .174 \\
\hline Kocaeli Sanayi Odası & 1 & 1.672 .665 .941 \\
\hline Malatya Ticaret ve Sanayi Odası & 1 & 754.205 .294 \\
\hline Uşak Ticaret ve Sanayi Odası & 1 & 747.500 .894 \\
\hline TOPLAM & 55 & 51.753.278.179 \\
\hline
\end{tabular}

\subsection{COVID-19'un Tekstil, Deri ve Giyim Eşyası Sektörlerine Etkileri}

11 Mart 2020'de Dünya Sağlık Örgütü COVID-19'un global bir pandemi olduğunu duyurmuştur. Sonrasında milyonlarca kişinin bu virüsle enfekte olması ve birçok insanın da hayatını kaybetmesi nedeniyle COVID-19 bütün ülkelerde ciddi karmaşa yaratmıştır (Kanno, 2021:1).

COVID-19'un yayılmasını engellemek amacıyla, faaliyetlerini sürdürmesi hayati olmayan işletmeler zorunlu olarak kapatılmış, insanların hareketliliğini kısıtlamak için sokağa çıkma yasakları ve seyahat yasakları (seyahat kısıtlamaları ve sınırların kapatılması) uygulanmış, ancak bunlar da ekonomik faaliyetleri önemli ölçüde daraltmıştır (Chen ve Yeh, 2021:1).

Pandemi nedeniyle alınan tedbirler, tekstil ve hazır giyim sektörünü de önemli ölçüde etkilemiştir. Karantina ve evden çıkma yasakları sonucunda yurt içi ve yurt dışı pazarlardaki daralma, tekstil sektörünü tarihinin en kötü likidite krizlerinden biriyle karşı karşıya bırakmıştır (Malik ve Khaver, 2020:3).

Tekstil sektörünü hem arz hem talep anlamında etkileyen COVID-19 pandemisinin etkileri, aşağıdaki tabloda özetlenmiştir.

\begin{tabular}{|l|l|l|}
\hline \multicolumn{2}{|l|}{ Tablo 2: Pandemi ile İlgili Tedbirlerin ve Ekonomik Olumsuzlukların Tekstil Sektörüne Yansımaları } \\
\hline Faktör & Etkileri & Tekstil Sektörüne Yansımaları \\
\hline Sosyal Mesafe & $\begin{array}{l}\text { AVM gibi mekanların ve perakende zincirlerin } \\
\text { kapalı olması }\end{array}$ & $\begin{array}{l}\text { Sağlıkla ilgili endişeler ve tüketicilerin olabildiğince riskten } \\
\text { kaçınmak istemeri nedeniyle tekstil ürünleri satın almaya } \\
\text { yönelik tüketici ilgisinin azalması ve firmaların hasılatlarının } \\
\text { düşmesi }\end{array}$ \\
\hline $\begin{array}{l}\text { Genel Ekonomik } \\
\text { Durum ve } \\
\text { İstihdam }\end{array}$ & $\begin{array}{l}\text { Pandeminin işletmelerin finansal durumlarında } \\
\text { yarattı̆̆ bozulmalar nedeniyle istihdamın } \\
\text { azalması, çalı̧anların ücretlerinde kesintiler } \\
\text { olması veya çalışanlara ücretsiz izin } \\
\text { kullandırılması }\end{array}$ & $\begin{array}{l}\text { Tüketicilerin finansal durumlarındaki bozulma sonucunda } \\
\text { zorunlu temel ihtiyaçlar dışındaki ürün ve hizmetlerin talebinde } \\
\text { genel düşüşs }\end{array}$ \\
\hline Uzaktan Çalışma & $\begin{array}{l}\text { Pandemi nedeniyle birçok işletmenin uzaktan/ } \\
\text { evden çalışma sistemine geçmesi }\end{array}$ & $\begin{array}{l}\text { Çalışanların iş yerlerine gitmek yerine evden çalışmaları ve hafta } \\
\text { sonları da genellikle sokağa çıkma yasaklarının uygulanması } \\
\text { nedeniyle tekstil ürünlerine olan talebin düşmesi }\end{array}$ \\
\hline İhracat Yasakları & $\begin{array}{l}\text { Bu faktör, tekstil gibi ihracat yoğun sektörler } \\
\text { için önemli bir ekonomik yansımaya sahiptir. }\end{array}$ & $\begin{array}{l}\text { Pandemi tedbirlerinden en önemlisi olan yüz maskelerinin üretimi } \\
\text { için hayati olan hammaddelerin üzerindeki baskılanmış küresel } \\
\text { talep ve ihracat yasakları nedeniyle yaşanan zorluklar }\end{array}$ \\
\hline Üretim & $\begin{array}{l}\text { Fabrikaların ve işletmelerin kapanması ve sosyal } \\
\text { mesafe kurallarını katı bir şekilde uygulanmas1 } \\
\text { sonucunda üretim faaliyetleri yavaşlamıştır. }\end{array}$ & $\begin{array}{l}\text { Üretim faaliyetlerinin yavaşlamasının, işletmelerin stoklarını } \\
\text { azaltması ve satı̧ fiyatları üzerinde yukarı yönlü bask1 yaratması }\end{array}$ \\
\hline
\end{tabular}




\begin{tabular}{|l|l|l|}
\hline Tedarik Zinciri & $\begin{array}{l}\text { Başta Çin olmak üzere büyük tekstil } \\
\text { üreticilerinin üretim faaliyetlerinin durması } \\
\text { nedeniyle tekstil sektöründe tedarik zincirleri } \\
\text { kesintiye uğramıştır. }\end{array}$ & $\begin{array}{l}\text { Ürün arzında ve tedarik zincirinde yaşanan kesintiler nedeniyle } \\
\text { tekstil, özellikle hazır giyim üreticilerinin, Çin dışında alternatif } \\
\text { tedarikçi bulma çabaları. }\end{array}$ \\
\hline $\begin{array}{l}\text { Ithal Hammadde } \\
\text { Fiyatları }\end{array}$ & $\begin{array}{l}\text { Suni (yapay) elyaf gibi ithal temel hammadde } \\
\text { fiyatlarındaki artış ve ayrıca artan döviz kurları } \\
\text { nedeniyle maliyetler artmıştır. }\end{array}$ & $\begin{array}{l}\text { Tekstil üretim süreçlerine yönelik hammadde girdilerinin } \\
\text { fiyatlarındaki artışın ithalatçıların maliyet etkinliğini ve hazır } \\
\text { giyim sektöründeki küresel rekabet gücünü azaltması ve ayrıca, } \\
\text { artan maliyetlerin fiyatları artırmasıyla birlikte talebin düşmesi }\end{array}$ \\
\hline
\end{tabular}

Kaynak: Kanupriya, 2021:9.

COVID-19 pandemisinin Türkiye açısından etkileri öncelikle ihracat verilerine yansımıştır. İHKİB (İstanbul Hazır Giyim ve Konfeksiyon İhracatçıları Birliği) tarafından açıklanan raporlar kullanılarak yapılan özet tablo verileri dikkate alındığında, Dünya Sağlık Örgütü’nün Mart 2020'de pandemi açıklamasıyla birlikte Mart 2020 hazır giyim ve konfeksiyon ihracat rakamının bir önceki aya göre \%20 ve 2019 yılının Mart ayına göre de yaklaşık \%28 oranında düştüğü görülmektedir. Ancak krizin etkisinin esas Nisan ve Mayıs aylarında kendini gösterdiği, Nisan 2020'de hazır giyim ve konfeksiyon ihracatının önceki yılın aynı ayına göre yaklaşık \%62 oranında azaldığı, Mayıs 2020'de ise Mayıs 2019'a göre \%48 azalarak son 18 aydaki en düşük seviyelere Nisan 2020 ve Mayıs 2020 aylarında ulaşıldığ belirlenmiştir. 2020 yılının ilk 6 ayının toplam ihracat rakamı ile 2021 yılının ilk 6 ayının toplam ihracat rakamları karşılaştıııldığında, 2021 yılında sektörde bir toparlanma yaşandığı ve önceki yıla göre ihracat rakamında \%35,7’lik bir artış olduğu hesaplanmaktadır.

Tablo 3: Türkiye’nin Hazır Giyim ve Konfeksiyon İhracat1 - 2020 ve 2021 Y1llar1

\begin{tabular}{|l|c|c|c|}
\hline & Hazır Giyim ve Konfeksiyon İhracatı (\$) & Önceki Aya Göre Değişim (\%) & $\begin{array}{c}\text { Önceki Yılın Aynı Ayına Göre } \\
\text { Değişim (\%) }\end{array}$ \\
\hline Ocak 2020 & 1.490 .276 .000 & 12,36 & 5,39 \\
\hline Şubat 2020 & 1.516 .935 .000 & 1,79 & $-27,73$ \\
\hline Mart 2020 & 1.209 .798 .000 & $-20,25$ & $-61,84$ \\
\hline Nisan 2020 & 573.278 .000 & $-52,61$ & $-48,43$ \\
\hline May1s 2020 & 835.979 .000 & 45,82 & 24,21 \\
\hline Haziran 2020 & 1.348 .588 .000 & 61,32 & 8,44 \\
\hline Temmuz 2020 & 1.812 .845 .000 & 34,43 & 10,87 \\
\hline Ağustos 2020 & 1.545 .731 .000 & $-14,73$ & 19,88 \\
\hline Eylü1 2020 & 1.797 .606 .000 & 16,29 & 19,63 \\
\hline Ekim 2020 & 1.857 .564 .000 & 3,34 & $-0,88$ \\
\hline Kasim 2020 & 1.523 .645 .000 & $-17,98$ & 25,30 \\
\hline Aralık 2020 & 1.661 .882 .000 & 9,07 & 2,20 \\
\hline Ocak 2021 & 1.523 .136 .000 & $-8,35$ & 0,03 \\
\hline Şubat 2021 & 1.517 .344 .000 & $-0,38$ & 38,69 \\
\hline Mart 2021 & 1.677 .874 .000 & 10,58 & 184,69 \\
\hline Nisan 2021 & 1.632 .042 .000 & $-2,73$ & 55,95 \\
\hline May1s 2021 & 1.303 .736 .000 & $-20,12$ & 34,07 \\
\hline Haziran 2021 & 1.808 .054 .000 & 38,68 & \\
\hline Kaynak:https://www.ihkib.org.tr/fp-icerik/ia/d/2021/07/05/hazirgiyim-ve-konfeksiyon-sektoru-2021-haziran-aylik-ihracat-bilgi-notu-202107051109110903- \\
\hline 932C7.pdf web sitesinde yer alan verilerden özetlenmiştir.
\end{tabular}

Özellikle hammadde tedariğini Çin'den sağlayarak, işlediği ürünleri ihraç eden Türkiye için, pandemiyle birlikte Çin'den yapılan ara mal tedariğinde yaşanan sıkıntılar ve ayrıca genel olarak dünyada tekstil ürünlerine olan talepteki azalış, Türkiye'nin tekstil imalatında da kapasitelerin ve ihracatın düşmesine neden olmuştur (Çatuk ve Aydın, 2021:441).

Tekstil, deri ve giyim ürünleri üreticilerinden tedarik sağlayan alıcılar, tüketicilerin sokağa çıkma yasakları veya COVID19 virüsünü kapma endişesi ile evlerinde kilitli kalması, alışveriş merkezlerinin kapalı olması ve online satışlara bazı alıcıların erişemiyor olması nedeniyle siparişlerini ya iptal etmiş ya da beklemeye almıştır. Ayrıca sosyal mesafe ve hijyen önlemlerinin getirdiği ek maliyetler, perakende satış fiyatlarında artış yaratıış (Kumar, Kumar ve Kalapna, 2021:314) ve COVID-19'un ekonomilerde yarattı̆̆ bozulma ve kişilerin alım gücündeki zayıflamayla da birleşerek, zaten düşük olan talebi daha da azaltmıştır. 
COVID-19 pandemisinin yarattığı finansal sıkıntılar nedeniyle müşterilerin ödemelerini geciktirmeleri veya hiç yapamamaları ve artan finansman maliyetleri nedeniyle finansman kaynaklarına erişimde zorluklar yaşanması, işletmelerin nakit yönetiminde de sorunlar yaratmıştır (Cavlak, 2020:151-152).

\section{Literatür Taraması}

COVID-19'un ekonomik sonuçları ortaya çıkmaya devam ettikçe, küresel finans piyasaları üzerindeki etkilerinin tespit edilmesine yönelik daha fazla çalışma yapılmaya başlanmıştır. Ancak bu çalışmaların çoğu, hisse senedi fiyatlarındaki değişim ve hisse senedi piyasası volatilitesi ile ilgilidir. COVID-19'un işletmelerin performansı üzerindeki sektöre özgü etkilerini araştıran çok daha az çalışma bulunmaktadır (Cho ve Saki, 2021:2).

Mishra ve Mishra (2021), 51 akademisyen ve finansal uzmanla yaptıkları anket sonucunda otomotiv sektörünü pandemiden çok ciddi şekilde etkilenmiş olarak sınıflandırırken, ulaşım, otel ve tekstil sektörlerini de ciddi şekilde etkilenmiş olarak kategorize etmiştir.

Cho ve Saki (2021) yaptıkları çalışmada COVID-19'un halka açık 55 ABD tekstil ve hazır giyim firmasının performansı üzerindeki etkisini araştırmış ve salgının ardından firmaların performansında keskin bir düşüş yaşandığını, tekstil ve hazır giyim sektörünün, ulaşım, eğlence ve konaklama dahil olmak üzere diğer sektörlerden daha fazla olumsuz etkilendiğini belirlemiştir.

Kaur (2021), Hindistan'daki 123 tekstil girişimcisine yaptığı anketle COVID-19 pandemisi nedeniyle yaşanan sorunları belirlemeye yönelik bir çalışma yapmıştır. Anket sonuçlarına göre COVID’le ilgili etkiler; önceden verilmiş olan siparişlerin ertelenmesi veya iptali nedeniyle işletme sermayesi ve istihdam sorunları, pandemi döneminde e-pazarlama, e-ödeme gibi dijital yeteneklerle donatılma imkanı, gelecekteki pazar promosyonlarının nasıl yapılacağına ve finansmanına dair endişeler, krizin getirdiği fırsatlar (maske üretimi, vb.), çalışanların fiziksel ve ruhsal sağlıklarıyla ilgili hususlar ve pandemi sürecinde transit malların teslim durumuyla ilgili belirsizliklerdir. Bazı anket katılımcıları, COVID-19 pandemisinin işlerini hiç etkilemediğini belirtmiştir. Ayrıca pandemi esnasındaki belirsizlikler ve sorunlar nedeniyle, tekstil girişimcilerinin stres düzeylerinin yüksek olduğu ve yaklaşı \%80'inin fiziksel veya ruhsal bir hastalıktan muzdarip olduğu tespit edilmiştir.

Szczygielski ve diğerleri (2021) ARCH/GARCH modellerini kullanarak COVID-19'la ilgili belirsizliğin küresel endüstri getirileri ve volatilitesi üzerindeki etkisinin ve rolünün kapsamlı bir analizini yaptıkları çalışmada, COVID-19'la ilişkili belirsizliğin tüm sektörlerin getirilerini olumsuz etkilediğini ve genel olarak daha yüksek oynaklığa yol açtığını görmüştür. Ancak, COVID-19'un yarattığı belirsiz iklime rağmen, bazı endüstrilerin iyi performans gösterdiği ve zaman zaman COVID-19 öncesi dönemden daha yüksek pozitif kümülatif anormal getiriler sağlandığı da belirlenmiştir.

Orhan ve Tirman (2020) COVID-19'un BİST-100'de yer alan ve on beş sektörde faaliyet gösteren işletmelere etkisine ilişkin ampirik bir analiz gerçekleştirmiştir. Analiz, 2018 ve 2019 yıllarının aynı dönemleri ile karşılaştırmalı olarak 11 Mart -11 Nisan 2020 dönemi için yapılmıştır. Türkiye'de COVID-19'un ilk döneminde en kârlı sektör \%9,21 getiri ile "sağlık ve ilaç sektörü" iken, bu dönemde getirisinde en fazla kayıp görülen sektörün -\%17,40 ile "giyim ve tekstil sektörü" olduğu tespit edilmiştir.

Aydın ve diğerlerinin (2021), COVID-19'un tekstil, giyim eşyası ve deri sektöründeki işletmelerin finansal tablolarına etkilerini değerlendirdikleri çalışmada, pandemiyle birlikte işletmelerin likiditesinin arttı̆̆ olmadığı, kısa vadeli borçlanmalardaki artış nedeniyle finansal risk düzeylerinin yükseldiği belirlenmiştir.

COVID-19 döneminde yapılan çalışmaların çoğu, hisse senedi anormal getirileri ve endekslerin volatilitesi ile ilgiliyken, Cui ve diğerleri (2021) konuya raporlama perspektifinden bakmıştır. Yaptıkları çalışmada, Şanghay ve Shenzhen Menkul Kıymetler Borsası'nda işlem gören ve daha koşullu ihtiyatlılık temelinde raporlama yapan Çinli firmaların, diğer firmalara kıyasla COVID-19 salgını sırasında hisse senedi getirisi performansında daha düşük düşüş olduğu ve ayrıca COVID-19 pandemisiyle birlikte firmaların daha fazla bilgi asimetrisine maruz kaldığında, koşullu ihtiyatlılığın faydalı rolünün daha yüksek olduğu görülmüştür. 
Benzer şekilde Cavlak (2020), BİST-100'de listelenen işletmelerin 2020 yılı ilk çeyrek ara dönem raporlarını inceleyerek COVID-19'un finansal raporlama üzerindeki olası etkilerini belirlemiştir. Çalışma sonuçlarına göre en detaylı açıklamaları bankaların yaptığı, COVID-19'la ilgili açıklamaların en çok raporlama döneminden sonraki olaylar ile ilgili dipnotta yer aldığı, işletmelerin çoğunun en az bir başlıkta COVID-19'a değindikleri ancak işletmenin sürekliliği, muhasebe tahminleri ve politikaları gibi kritik başlıklarda pek fazla yer vermedikleri görülmüştür.

\section{COVID-19 Pandemisinin BİST’te ve Tekstil, Deri ve Giyim Eşyası Sektörlerinde Faaliyet Gösteren Firmalara ve Finansal Raporlarına Etkileri şeklinde düzelecek}

\section{1. Çalışmanın Amacı}

Bu çalışmanın amacı, pandeminin yaşandığı ilk yılın sonu olan 31 Aralık 2020 tarihi itibariyle COVID-19'un tekstil, deri ve giyim eşyası sektörlerinde faaliyet gösteren işletmelerin finansal durum ve performanslarına etkisinin ve halka açıklanan finansal raporlarda yarattığı değişikliklerin tespit edilmesidir.

$\mathrm{Bu}$ amaçla BİST’te listelenen ve ilgili sektörlerde faaliyet gösteren bütün işletmelerin finansal tabloları ve dipnotları incelenerek COVID-19'un finansal etkilerinin belirlenmesine yönelik finansal veriler ve COVID-19'la ilgili olarak işletmelerin yaptıkları dipnot açıklamaları özetlenmiş ve analiz edilmiştir.

\section{2. Çalışmanın Yöntemi ve Veri Seti}

Çalışmaya, Kamuyu Aydınlatma Platformu'nda (KAP) yer alan sektör sınıflandırmasına göre tekstil, giyim eşyası ve deri sektöründe kategorize edilmiş 21 işletmeden 19 tanesi ile perakende ticaret sektörü altında yer alan 2 işletme (Mavi Giyim ve Vakko Tekstil) dahil edilmiştir. Kordsa Teknik Tekstil A.Ş.'nin KAP’ta yer alan faaliyet konusu "araç lastiklerinin yapısında bulunan ve ana iskeleti oluşturan bezler ile sınai tür bezlerin imalatı; transmisyon kayışları, V kayışları, lastik hortumlar gibi kauçuk ve plastik malzemenin yapısında bulunan sınai bezler ile sınai tek kordun imalatı"dır ve firma otomotiv sektörüne malzeme tedarik etmektedir. Bilici Yatırım ise iplik büküm, inşaat, turizm, enerji gibi farklı alanlarda faaliyet göstermektedir. Bu nedenle bu iki firma tekstil, giyim eşyası ve deri sektöründe sınıflandırılmış olmalarına rağmen çalışma kapsamı dışında bırakılmıştır. Çalışmada yer alan 21 firmanın listesi aşağıdaki tabloda yer almaktadır.

\begin{tabular}{|c|c|c|}
\hline Şirket Adı & KAP Sektörü & Ürünler1 \\
\hline Akın Tekstil & İmalat / Tekstil, Giyim Eşyası ve Deri & Kumaş, iplik ve konfeksiyon ürünleri \\
\hline Arsan Tekstil & İmalat / Tekstil, Giyim Eşyası ve Deri & $\begin{array}{l}\text { Pamuk ipliği ve sentetik iplik, örme kumaş, } \\
\text { dokuma kumaş ve boya faaliyetleri }\end{array}$ \\
\hline $\begin{array}{l}\text { Birko Birleşik Koyunlular } \\
\text { Mensucat }\end{array}$ & İmalat / Tekstil, Giyim Eşyası ve Deri & Halı \\
\hline Birlik Mensucat & İmalat / Tekstil, Giyim Eşyası ve Deri & $\begin{array}{l}\text { Mamul bez, havlu, ev tekstili, yatak, baza ve başlık } \\
\text { ürünleri }\end{array}$ \\
\hline Bossa Ticaret ve Sanayi & İmalat / Tekstil, Giyim Eşyası ve Deri & Tekstil ürünleri \\
\hline Dagi Giyim & İmalat / Tekstil, Giyim Eşyası ve Deri & Tekstil ürünleri \\
\hline Derimod Konfeksiyon & İmalat / Tekstil, Giyim Eşyası ve Deri & Giysi, ayakkabı ve çanta \\
\hline Desa Deri & İmalat / Tekstil, Giyim Eşyası ve Deri & $\begin{array}{l}\text { Deri konfeksiyon, çanta, ayakkabı ve her çeşit } \\
\text { saraciye mamulleri }\end{array}$ \\
\hline Diriteks Diriliş Tekstil & İmalat / Tekstil, Giyim Eşyası ve Deri & Akrilik iplik, battaniye ve kaymaz halı \\
\hline Hateks Hatay Tekstil & İmalat / Tekstil, Giyim Eşyası ve Deri & $\begin{array}{l}\text { İplik, dokuma, boyama, konfeksiyon ve ev tekstili } \\
\text { ürünleri }\end{array}$ \\
\hline Karsu Tekstil & İmalat / Tekstil, Giyim Eşyası ve Deri & $\begin{array}{l}\text { İplik, boyama, ham ve mamul örgü kumaş, boyalı } \\
\text { kumaş }\end{array}$ \\
\hline Lüks Kadife Ticaret & İmalat / Tekstil, Giyim Eşyası ve Deri & $\begin{array}{l}\text { Döşemelik, perdelik ve konfeksiyonluk kadife } \\
\text { kumaş }\end{array}$ \\
\hline Mavi Giyim & $\begin{array}{l}\text { Toptan ve Perakende Ticaret, Lokantalar ve } \\
\text { Oteller / Perakende Ticaret }\end{array}$ & Denim odaklı hazır giyim \\
\hline
\end{tabular}

Tablodaki "Ürünler” kısmı, işletmelerin faaliyet raporlarında yer alan bilgilerin incelenmesi ve özetlenmesi ile oluşturulmuştur. 


\begin{tabular}{|l|l|l|}
\hline Menderes Tekstil & İmalat / Tekstil, Giyim Eşyası ve Deri & $\begin{array}{l}\text { Preseli pamuk, iplik, ham bez, astar, } \\
\text { tela, nevresim, çarşaf, gömleklik ve döşemelik bez }\end{array}$ \\
\hline Rodrigo Tekstil & İmalat / Tekstil, Giyim Eşyası ve Deri & Erkek giyim \\
\hline Royal Halı & İmalat / Tekstil, Giyim Eşyası ve Deri & Halı ve iplik \\
\hline Söktaş Tekstil & İmalat / Tekstil, Giyim Eşyası ve Deri & İplik ve kumaş \\
\hline Sönmez Pamuklu Sanayii & İmalat / Tekstil, Giyim Eşyası ve Deri & İplik ve kumaş \\
\hline Vakko Tekstil & $\begin{array}{l}\text { Toptan ve Perakende Ticaret, Lokantalar ve } \\
\text { Oteller / Perakende Ticaret }\end{array}$ & Emprime bask1 ve hazır giyim \\
\hline Yataş Yatak ve Yorgan & İmalat / Tekstil, Giyim Eşyası ve Deri & $\begin{array}{l}\text { Yatak, modüler mobilya, yorgan, koltuk, kanepe, } \\
\text { ev tekstili ve ev mobilyası }\end{array}$ \\
\hline Yünsa Yünlü & İmalat / Tekstil, Giyim Eşyası ve Deri & Yünlü tekstil mamulleri \\
\hline
\end{tabular}

COVID-19'un işletmelerin finansal durumu ve performansı üzerindeki etkilerinin tespiti amacıyla, işletmelerin KAP'ta yayınlanmış bağımsız denetimden geçmiş raporları içerik analizine tabi tutulmuştur. 2019 ve 2020 yıllarına ait finansal verilerin yatay analizi ve rasyo analizi yapılarak pandemi yılındaki değişimler tespit edilmiştir. Ayrıca raporlardaki dipnotlar analiz edilerek işletmelerin COVID-19’a ilişkin olarak yaptıkları açıklamalar değerlendirilmiştir.

\subsection{Araştırmanın Bulguları}

\subsubsection{COVID-19’un Finansal Durum ve Finansal Performans Üzerindeki Etkileri}

Tekstil, giyim eşyası ve deri sektöründe faaliyet gösteren işletmelerin 2019 ve 2020 yıl sonu finansal verileri dikkate alınarak finansal durum tablosunda yer alan kalemler için yüzdesel değişimler (yatay analiz) hesaplanmıştır.

\begin{tabular}{|l|c|c|c|c|c|c|c|}
\hline Tablo 5: 2019-2020 Y1lları Arasında Finansal Durum Tablosunun Bazı Kalemlerinde Meydana Gelen Yüzdesel Değişimler (\%) \\
\hline & $\begin{array}{c}\text { Dönen } \\
\text { Varlıklar }\end{array}$ & $\begin{array}{c}\text { Duran } \\
\text { Varlıklar }\end{array}$ & $\begin{array}{c}\text { Toplam } \\
\text { Varlıklar }\end{array}$ & KVYK & UVYK & $\begin{array}{c}\text { Toplam } \\
\text { Yükümlülükler }\end{array}$ & Özkaynaklar \\
\hline Akın Tekstil & $-3,81$ & 10,33 & 6,14 & $-19,98$ & 32,21 & $-4,36$ & 11,92 \\
\hline Arsan Tekstil & $-4,04$ & 13,83 & 8,34 & $-53,22$ & 8,28 & $-31,02$ & 33,46 \\
\hline Birko Birleşik & 10,43 & 19,93 & 18,36 & $-31,19$ & 169,47 & $-0,95$ & 31,02 \\
\hline Birlik Mensucat & $-24,76$ & $-95,55$ & $-94,11$ & $-78,18$ & $-59,28$ & $-75,89$ & $-143,19$ \\
\hline Bossa Ticaret ve Sanayi & 28,32 & 1,93 & 14,21 & 21,12 & $-0,52$ & 11,19 & 23,31 \\
\hline Dagi Giyim & 17,49 & 75,10 & 50,97 & 38,42 & 23,26 & 32,33 & 70,48 \\
\hline Derimod Konfeksiyon & $-3,30$ & $-11,16$ & $-3,43$ & 4,89 & $-37,16$ & $-2,31$ & $-7,12$ \\
\hline Desa Deri & 9,67 & $-26,74$ & $-4,15$ & $-27,11$ & 70,65 & $-5,88$ & 0,91 \\
\hline Diriteks Diriliş Tekstil & 230,50 & 26,12 & 34,23 & 39,73 & 5,94 & 21,46 & 156,26 \\
\hline Hateks Hatay Tekstil & 42,35 & $-2,61$ & 8,86 & 24,81 & 17,59 & 23,24 & 3,04 \\
\hline Karsu Tekstil & 30,41 & 84,38 & 50,36 & 25,20 & 45,80 & 32,83 & 135,30 \\
\hline Lüks Kadife Ticaret & 38,67 & 9,53 & 19,96 & 57,34 & 11,12 & 25,65 & 14,78 \\
\hline Mavi Giyim & 59,72 & 12,49 & 39,76 & 59,04 & 15,15 & 48,91 & 11,80 \\
\hline Menderes Tekstil & 46,75 & 100,52 & 74,81 & 17,49 & 88,29 & 44,86 & 297,99 \\
\hline Rodrigo Tekstil & 2,46 & 72,51 & 22,21 & 12,09 & 133,35 & 32,38 & 8,66 \\
\hline Royal Hal1 & 25,89 & 32,12 & 27,01 & $-1,61$ & 54,01 & 18,59 & 194,03 \\
\hline Söktaş Tekstil & 31,11 & 40,19 & 37,93 & 34,91 & 3,63 & 19,12 & 196,00 \\
\hline Sönmez Pamuklu & 16,84 & 0,66 & 3,47 & $-1,75$ & 2,28 & 0,79 & 4,57 \\
\hline Vakko Tekstil & 21,59 & 5,86 & 14,17 & $-5,27$ & 47,44 & 11,65 & 20,37 \\
\hline Yataş Yatak ve Yorgan & 80,21 & 19,05 & 51,59 & 51,60 & 90,03 & 62,78 & 35,94 \\
\hline Yünsa Yünlü & $-5,14$ & 12,25 & $-0,61$ & $-31,10$ & 242,21 & $-5,48$ & 12,56 \\
\hline
\end{tabular}

Varlıklar, yükümlülükler ve özkaynaklar bakımından değerlendirme yapıldığında, hepsinde \%70'in üzerinde düşüş görülen tek firma Birlik Mensucat'tır. Ancak Birlik Mensucat'ın finansal durum ve performansındaki sorunların 2020 yılında oluşmadığı, işletmenin 2019 yılında da 2020 yılındakine yakın tutarda dönem zararına sahip olduğu, ayrıca dönem zararına ek olarak özkaynaktaki düşüşün önemli bir sebebinin bir gayrimenkulün şirket ortaklarından birine 31 Aralık 2019 tarihli gerçeğe uygun değerinden \%30 düşük bir bedelle satılmış olması olduğu belirlenmiştir. Söz konusu işlem denetim şirketi tarafından "sınırlı olumlu görüş" verilmesinin de gerekçelerinden biri olmuştur. 
Birkaç firma (Yünsa Yünlü, Arsan Tekstil, Akın Tekstil, Derimod, Desa Deri ve Hateks Hatay Tekstil) dışındaki firmaların hepsinin dönen ve duran varlıklarında artış görülmektedir. Dönen varlıklardaki artışların sebebi nakit ve nakit benzerlerindeki, ticari alacaklardaki ve stoklardaki artışlardır. Duran varlıklardaki artış ise genellikle yatırım amaçlı gayrimenkullerin ve maddi duran varlıkların yeniden değerlenmesinden kaynaklanmaktadır. Pandemi yılında çok az işletmede duran varlık yatırımı yapılmış olup, bunlar da çok yüksek tutarlı işlemler değildir.

Dokuz firmanın kısa vadeli yükümlülükleri azalırken, yalnızca üç firmanın uzun vadeli yükümlülükleri azalmıştır. Onlar dışındaki bütün firmaların hem kısa vadeli hem de uzun vadeli yükümlülüklerinde artış olduğu gözlemlenmektedir. Birlik Mensucat ve Akın Tekstil dışındaki bütün işletmelerin özkaynaklarında 2020 yılında artış olmuştur.

Tablo 6: 2019-2020 Yılları Arasında Kâr veya Zarar Tablosunun Bazı Kalemlerinde Meydana Gelen Yüzdesel Değişimler (\%)

\begin{tabular}{|l|c|c|c|c|c|c|c|c|}
\hline & Hasılat & $\begin{array}{c}\text { Yurt Dışı } \\
\text { Hasılat }\end{array}$ & $\begin{array}{c}\text { Satışların } \\
\text { Maliyeti }\end{array}$ & $\begin{array}{c}\text { Brüt } \\
\text { Kâr }\end{array}$ & $\begin{array}{c}\text { Esas } \\
\text { Faaliyet } \\
\text { Kârı }\end{array}$ & $\begin{array}{c}\text { Finansman } \\
\text { Geliri (Gideri) } \\
\text { On.Faal.Kârı }\end{array}$ & $\begin{array}{c}\text { Finansal } \\
\text { Giderler }\end{array}$ & $\begin{array}{c}\text { Dönem Kârı/ } \\
\text { Zararı }\end{array}$ \\
\hline Akın Tekstil & $-28,44$ & $-26,88$ & $-33,25$ & $-8,18$ & 186,09 & 184,02 & 118,27 & 230,31 \\
\hline Arsan Tekstil & $-5,83$ & 5,94 & $-7,73$ & 6,38 & 57,98 & 66,01 & 14,57 & 84,30 \\
\hline Birko Birleşik & 31,16 & - & 0,42 & 739,44 & 99,50 & 272,01 & $-38,50$ & 68,62 \\
\hline Birlik Mensucat & $-8,48$ & - & $-24,93$ & 5,89 & $-398,53$ & $-189,58$ & $-27,78$ & $-1,91$ \\
\hline Bossa Ticaret ve Sanayi & 1,78 & $-1,48$ & $-11,58$ & 41,11 & $-79,30$ & 43,82 & 130,49 & 42,50 \\
\hline Dagi Giyim & $-9,38$ & 150,41 & $-4,42$ & $-14,84$ & $-47,22$ & 20,48 & $-17,09$ & 55,91 \\
\hline Derimod Konfeksiyon & $-12,44$ & - & $-11,11$ & $-25,20$ & $-54,63$ & $-54,63$ & $-45,98$ & 15,59 \\
\hline Desa Deri & $-45,48$ & $-53,59$ & $-55,85$ & $-28,41$ & $-32,11$ & $-38,66$ & 39,02 & $-90,97$ \\
\hline Diriteks Diriliş Tekstil & $-20,24$ & - & $-59,79$ & 93,13 & 77,25 & 84,33 & $-11,97$ & 68,95 \\
\hline Hateks Hatay Tekstil & 15,15 & 13,62 & 1,00 & 148,08 & 156,47 & $-10,49$ & 11,46 & $-43,00$ \\
\hline Karsu Tekstil & 7,57 & 25,45 & $-4,13$ & 77,52 & 85,11 & 90,21 & 59,37 & 524,99 \\
\hline Lüks Kadife Ticaret & 9,39 & $-15,49$ & $-12,83$ & 61,41 & 73,14 & 55,68 & 122,21 & $-38,39$ \\
\hline Mavi Giyim & $-16,11$ & $-6,40$ & $-14,85$ & $-17,41$ & $-74,96$ & $-75,30$ & 5,39 & $-92,54$ \\
\hline Menderes Tekstil & 24,82 & 21,03 & 13,00 & 126,66 & 164,33 & 136,90 & 116,21 & $-420,02$ \\
\hline Rodrigo Tekstil & $-22,58$ & $-98,68$ & $-10,91$ & $-31,42$ & $-84,67$ & $-87,90$ & 3,68 & $-199,14$ \\
\hline Royal Halı & $-4,58$ & 3,18 & $-17,49$ & 143,70 & 206,41 & 209,93 & 66,68 & 111,53 \\
\hline Söktaş Tekstil & $-11,01$ & $-9,88$ & $-15,85$ & 4,09 & 19,60 & $-36,52$ & 6,28 & $-238,97$ \\
\hline Sönmez Pamuklu & 6,73 & 165,85 & $-5,75$ & 44,55 & $-118,38$ & $-68,85$ & 70,89 & $-80,50$ \\
\hline Vakko Tekstil & $-23,18$ & $-79,15$ & $-21,11$ & $-25,07$ & $-71,21$ & $-71,15$ & $-20,57$ & $-84,00$ \\
\hline Yataş Yatak ve Yorgan & 49,80 & 43,50 & 55,70 & 41,42 & 66,32 & 65,55 & 38,69 & 97,29 \\
\hline Yünsa Yünlü & $-35,84$ & $-27,40$ & $-40,63$ & $-10,91$ & 9,67 & 47,48 & $-0,59$ & 98,86 \\
\hline
\end{tabular}

Hasılatlardaki değişimler incelendiğinde, 21 işletmeden 13 tanesinin hasılatının pandemi yılında düştüğü görülmektedir. Hasılatı artan 8 firmadan en yüksek hasılat artışına sahip 2 firmanın (Birko Birleşik Koyunlular Mensucat ve Yataş Yatak ve Yorgan) hazır giyimden ziyade halı, ev tekstili, yatak, yorgan, koltuk, kanepe üretimi alanlarında faaliyet gösterdikleri görülmektedir. Sokağa çıkma yasakları gibi COVID-19 kapsamında alınan tedbirler ve uzaktan çalışma nedeniyle insanların evde daha fazla zaman geçirmeleri, ev konforuna yönelik ev eşyaları ve ev tekstiline olan talebi artırmıştır. Ancak yine aynı gerekçeler nedeniyle, insanların zamanlarının çoğunu evde geçirmeleri sonucunda hazır giyim, ayakkabı ve çanta üreten veya perakende satışını yapan firmaların genel olarak hasılatlarında düşüş yaşanmıştır. Hasılatı artan tekstil fïrmaları daha ağırlıklı olarak iplik, boyalı kumaş, astar gibi hazır giyim hammaddelerini üretip satan firmalardır. Bu artışın sebebinin COVID-19 pandemisinde tedarik zincirinde yaşanan bozulmalar ve özellikle de Çin'den yapılan hammadde ithalatındaki aksaklıklar kaynaklı olması muhtemeldir.

Kârdaki düşüşü veya zarardaki artışı en yüksek olan firmaların kâr veya zarar tabloları incelendiğinde, pandemi esnasında kârlılığa olumsuz etki yapan faktörlerin hasılattaki azalış, finansman giderlerindeki artış, özkaynak yöntemiyle değerlenen yatırımların paylarından kârlar/zararlar ve kur farkı giderleri olduğu belirlenmiştir. Bu sonucun önemli kalemlerinden biri olan yüksek finansman giderleri, hem pandemi sürecinde işletmelerin daha likit olabilmek için daha fazla borçlanmalarından, hem de borçlanma faiz oranlarının piyasa koşulları nedeniyle yükselmiş olmasından kaynaklanmaktadır. 


\begin{tabular}{|c|c|c|c|c|}
\hline & \multicolumn{2}{|c|}{ Cari Oran } & \multicolumn{2}{|c|}{ Asit-Test Oranı } \\
\hline & 2019 & 2020 & 2019 & 2020 \\
\hline Akın Tekstil & 1,19 & 1,43 & 0,68 & 0,77 \\
\hline Arsan Tekstil & 1,23 & 2,53 & 0,87 & 1,88 \\
\hline Birko Birleşik & 0,49 & 0,79 & 0,06 & 0,15 \\
\hline Birlik Mensucat & 0,03 & 0,11 & 0,03 & 0,10 \\
\hline Bossa Ticaret ve Sanayi & 1,15 & 1,21 & 0,79 & 0,78 \\
\hline Dagi Giyim & 1,37 & 1,16 & 0,66 & 0,46 \\
\hline Derimod Konfeksiyon & 1,55 & 1,43 & 1,49 & 1,37 \\
\hline Desa Deri & 1,06 & 1,60 & 0,31 & 0,67 \\
\hline Diriteks Diriliş Tekstil & 0,08 & 0,19 & 0,07 & 0,19 \\
\hline Hateks Hatay Tekstil & 1,13 & 1,29 & 0,64 & 0,80 \\
\hline Karsu Tekstil & 1,21 & 1,26 & 0,79 & 0,90 \\
\hline Lüks Kadife Ticaret & 2,39 & 2,11 & 1,78 & 1,62 \\
\hline Mavi Giyim & 1,00 & 1,00 & 0,55 & 0,69 \\
\hline Menderes Tekstil & 0,88 & 1,10 & 0,32 & 0,59 \\
\hline Rodrigo Tekstil & 1,51 & 1,38 & 0,53 & 0,43 \\
\hline Royal Halı & 1,24 & 1,59 & 0,98 & 1,31 \\
\hline Söktaş Tekstil & 0,56 & 0,55 & 0,30 & 0,33 \\
\hline Sönmez Pamuklu & 1,62 & 1,93 & 0,99 & 1,35 \\
\hline Vakko Tekstil & 1,09 & 1,40 & 0,28 & 0,36 \\
\hline Yataş Yatak ve Yorgan & 1,29 & 1,53 & 0,73 & 0,92 \\
\hline Yünsa Yünlü & 1,12 & 1,54 & 0,60 & 0,81 \\
\hline
\end{tabular}

İşletmelerin likidite rasyoları incelendiğinde, beş işletmenin cari oranında, dört işletmenin de asit-test oranında 2020 yılında 2019'a kıyasla düşüş olduğu görülmektedir. Ancak genel olarak rasyolarda artış olduğu, düşüş olan firrmalardaki değişimin de sınırlı olduğu tespit edilmiştir.

Çoğu işletmenin hem kısa vadeli hem de uzun vadeli yabancı kaynaklarında artış görülürken, işletmelerin bir kısmında da kısa vadeli yabanıı kaynak kullanımını azaltarak uzun vadeli yabanıı kaynak kullanımına geçiş yaptıkları görülmüştür. Bu durumun, işletmelerin COVID-19 pandemisinin yarattığı belirsizlik ortamında nakit yaratma ve likiditeyi koruma çabalarından kaynaklanmış olması muhtemeldir. Bunun sonucunda da işletmelerin 2020 yılında bir önceki yıla kıyasla önemli bir likidite sorunu yaşamadıkları görülmektedir.

İşletmelerin likiditelerinde önemli bir bozulma veya değişme görülmezken, kârlılık rasyolarında pandemiyle birlikte daha belirgin bir değişim olmuştur. Desa Deri, Mavi Giyim, Rodrigo Tekstil, Sönmez Pamuklu, Söktaş Tekstil, Royal Halı, Birko Birleşik ve Vakko Tekstil işletmelerinin net kâr marjlarında \%76-\%281 aralığında düşüş yaşanmıştır. Akın Tekstil, Karsu Tekstil, Menderes Tekstil ve Yünsa Yünlü işletmelerinin net kâr marjlarında ise \%208-\%481 aralığında artış gerçekleşmiştir.

Kâr veya zarar tabloları incelendiğinde, 2020 yılında Akın Tekstil'in finansal giderlerinde önceki yıla kıyasla ciddi bir yükseliş olmasına rağmen, kârlılığı artıran tek nedenin yatırım amaçlı gayrimenkullerin değerlenmesinden kaynaklanan, gerçeğe uygun değer artışı olduğu görülmüştür. Karsu Tekstil ve Menderes Tekstil’deki kâr artışının ilk sebebi ilk madde ve malzeme giderlerindeki azalıştan kaynaklanan, geçmiş yıla kıyasla daha düşük satışların maliyeti kalemi raporlanmasıdır. Yine her iki işletmede de esas faaliyetlerden diğer gelirler kaleminde artış olduğu, Karsu Tekstil'de hem kambiyo kârları ve reeskont faiz gelirlerinde artış olduğu, Menderes Tekstil'de ise sadece kur farkı gelirlerinde artış olduğu belirlenmiştir. Benzer şekilde Yünsa'da da satışların maliyetinde ve pazarlama giderlerinde düşüş, esas faaliyetlerden diğer gelirlerde ise kur farkı gelirlerinden kaynaklanan bir artış olduğu görülmüştür. Pandemi döneminde işletmenin pazarlama giderleri kapsamında raporladığı ihracat ve navlun, danışmanlık, nakliyat, reklam, seyahat ve haberleşme, ihale ve kargo giderlerinde düşüş olduğu belirlenmiştir.

Genel olarak değerlendirme yapıldığında, 2020 yılında kârlılıktaki olumlu değişimlerin sebeplerinin çoğunun pandemiyle birebir ilişkili olmadığı, gerçeğe uygun değer artışı, kur farkı gelirleri, reeskont faiz gelirleri gibi esas faaliyetlerden diğer 
gelirler başlığı altında raporlanan kalemlerden kaynaklandığı görülmüştür. Pandemiden kaynaklanan ve kârlılığı artıran tek unsur ilk madde ve malzeme giderlerindeki azalıştır.

COVID-19 pandemisinin başlamasıyla birlikte insanlara yapılan "evde kal" çağrısı giyim ve tekstil ürün satışlarına önemli darbe vurmuş, bunun sonucunda da azalan taleple birlikte pamuk fiyatlarında ciddi bir düşüş yaşanmıştır (Dünya Gazetesi, 2020). Pamuk fiyatlarındaki düşüş de sektördeki firmaların kârlılığına olumlu yansımıştır.

Tablo 8: Kârlılık Rasyoları

\begin{tabular}{|c|c|c|c|c|c|c|c|c|c|c|c|c|c|c|}
\hline & \multicolumn{2}{|c|}{$\begin{array}{c}\text { Brüt Kâr Marjı } \\
(\%)\end{array}$} & \multicolumn{2}{|c|}{$\begin{array}{c}\text { Net Kâr Marjı } \\
(\%)\end{array}$} & \multicolumn{2}{|c|}{$\begin{array}{c}\text { Aktif Kârlılık } \\
\text { Oranı (\%) }\end{array}$} & \multicolumn{2}{|c|}{$\begin{array}{c}\text { Özkaynak } \\
\text { Kârlılığı (\%) }\end{array}$} & \multicolumn{2}{|c|}{$\begin{array}{c}\text { Faaliyet Kârı/ } \\
\text { Net Satışlar (\%) }\end{array}$} & \multicolumn{2}{|c|}{$\begin{array}{c}\text { Finans. } \\
\text { Giderleri/Net } \\
\text { Satışlar (\%) }\end{array}$} & \multicolumn{2}{|c|}{$\begin{array}{c}\text { Faiz Karşılama } \\
\text { Oranı }\end{array}$} \\
\hline & 2019 & 2020 & 2019 & 2020 & 2019 & 2020 & 2019 & 2020 & 2019 & 2020 & 2019 & 2020 & 2019 & 2020 \\
\hline Akın Tekstil & 19,21 & 24,64 & 2,83 & 13,07 & 1,73 & 5,27 & 2,60 & 7,95 & 5,35 & 21,41 & 4,57 & 13,95 & 1,73 & 1,94 \\
\hline Arsan Tekstil & 13,42 & 15,16 & 21,48 & 42,05 & 10,72 & 17,38 & 17,67 & 25,41 & 13,06 & 21,91 & 8,51 & 10,36 & 3,52 & 5,06 \\
\hline Birko Birleşik & $-4,15$ & 20,25 & $-59,16$ & $-14,15$ & $-8,19$ & $-2,44$ & $-13,12$ & $-3,82$ & $-32,63$ & $-0,12$ & 52,74 & 24,73 & $-0,12$ & 0,43 \\
\hline Birlik Mensucat & 53,39 & 61,77 & $-325,53$ & $-362,49$ & $-10,85$ & $-22,82$ & $-36,17$ & $-157,08$ & $-8,03$ & $-43,74$ & 389,52 & 307,38 & 0,16 & $-0,18$ \\
\hline Bossa Ticaret ve & 25,35 & 35,15 & 9,33 & 5,27 & 7,75 & 3,92 & 35,96 & 15,09 & 17,99 & 31,68 & 10,99 & 24,89 & 1,86 & 1,22 \\
\hline Dagi Giyim & 47,65 & 44,78 & 3,99 & 6,87 & 2,87 & 3,14 & 5,35 & 5,97 & 11,99 & 6,99 & 11,81 & 10,81 & 1,34 & 1,64 \\
\hline Derimod Kor & & & $-2,22$ & & $-2,04$ & & $-10,71$ & & & & 7,94 & 4,90 & 0,73 & 0,56 \\
\hline Desa Deri & 37,80 & 49,64 & 4,26 & 0,71 & 5,63 & 0,46 & 21,56 & 1,75 & 11,07 & 13,78 & 6,51 & 16,59 & 1,79 & 1,07 \\
\hline Diriteks Diril & $-118,63$ & $-10,22$ & $-474,88$ & $-184,89$ & $-41,57$ & $-14,99$ & $-233,34$ & - & $-349,77$ & $-99,75$ & 134,49 & 148,44 & $-2,53$ & $-0,25$ \\
\hline Hateks Hatay Te & & 20,73 & 13,48 & 6,67 & & & 10,79 & 5,15 & & 14,34 & 11,63 & 11,26 & 2,26 & 1,76 \\
\hline Karsu Tekstil & 14,33 & 23,65 & 1,04 & 6,04 & 0,91 & 4,29 & 5,15 & 18,70 & 19,60 & 33,72 & 17,44 & 25,84 & 1,06 & 1,24 \\
\hline Lüks Kadife T & 29,93 & 44,16 & 12,06 & 6,79 & 6,39 & 3,38 & 12,15 & 6,61 & 25,07 & 39,68 & 16,08 & 32,66 & 1,85 & 1,26 \\
\hline Mavi Giyim & 49,06 & & & & & & 26,48 & & 12,64 & & & 10,18 & 1,68 & 1,07 \\
\hline Menderes Tekstil & 10,40 & 18,88 & $-1,21$ & $-5,05$ & $-1,24$ & $-4,38$ & $-9,31$ & $-20,42$ & 6,96 & 14,75 & 13,58 & 23,52 & 0,91 & 0,79 \\
\hline Rodrigo Tekstil & 56,91 & 50,41 & 5,51 & $-7,05$ & 4,89 & $-4,09$ & 11,73 & $-10,16$ & 10,99 & 2,18 & 8,43 & 11,29 & 1,65 & 0,38 \\
\hline Royal Halı & & 20,45 & $-29,79$ & 360 & $-15,09$ & 1,55 & $\mid-516,01$ & - & $-23,79$ & 26,53 & 16,04 & 28,02 & $-0,86$ & 1,13 \\
\hline Söktaş Tekstil & 24,26 & 28,38 & $-4,19$ & $-15,97$ & $-2,10$ & $-7,03$ & $-14,94$ & $-39,71$ & 10,94 & 14,71 & 26,95 & 32,19 & 0,84 & 0,5 \\
\hline Sönmez Pamuklu & 24,80 & 33,59 & 50,28 & 9,19 & 19,78 & 3,35 & 29,38 & 4,69 & 6,85 & $-1,18$ & 3,25 & 5,20 & 16,49 & 2,77 \\
\hline Vakko Tekstil & 52,29 & 51,00 & 6,55 & 123 & 8,79 & 1,12 & 28,33 & 3,76 & 16,40 & 6,15 & 8,73 & 9,02 & 1,97 & 1,16 \\
\hline Yataş Yatak ve Yorgan & 41,35 & 39,04 & 7,39 & 9,73 & 10,47 & 14,47 & 24,74 & 37,00 & 13,11 & 14,55 & 4,26 & 3,94 & 3,29 & 4,18 \\
\hline Yünsa Yünlü & 16,12 & 22,39 & 1,09 & 3,36 & 1,55 & 3,08 & 5,64 & 10,71 & 4,61 & 7,88 & 4,29 & 6,65 & 1,25 & 1,51 \\
\hline
\end{tabular}

Tablo 9: Faaliyet ve Mali Yapı Rasyolar1

\begin{tabular}{|c|c|c|c|c|c|c|c|c|c|c|c|c|c|c|}
\hline & \multicolumn{2}{|c|}{$\begin{array}{c}\text { Stok Devir } \\
\text { Hizı }\end{array}$} & \multicolumn{2}{|c|}{$\begin{array}{c}\text { Alacak Devir } \\
\text { Hızı }\end{array}$} & \multicolumn{2}{|c|}{$\begin{array}{c}\text { Borç Devir } \\
\text { Hızı }\end{array}$} & \multicolumn{2}{|c|}{$\begin{array}{c}\text { Nakit } \\
\text { Çevirme / } \\
\text { Dönüş Süresi }\end{array}$} & \multicolumn{2}{|c|}{$\begin{array}{c}\text { Kaldıraç } \\
\text { Oranı }\end{array}$} & \multicolumn{2}{|c|}{\begin{tabular}{|c|} 
KV Yük./ \\
Toplam Pasif \\
(\%)
\end{tabular}} & \multicolumn{2}{|c|}{\begin{tabular}{|c|} 
UV Yük/ \\
Toplam Pasif \\
(\%)
\end{tabular}} \\
\hline & 2019 & 2020 & 2019 & 2020 & 2019 & 2020 & 2019 & 2020 & 2019 & 2020 & 2019 & 2020 & 2019 & 2020 \\
\hline il & 3,48 & & & & & & 7,50 & 122,23 & & & & & & \\
\hline & & & & & & & 127,74 & & & & & & 14,06 & \\
\hline & & & & & & & & & & & & & 5,97 & \\
\hline & 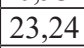 & & & & & & & & & & & & & \\
\hline & & & & & & & & & & & & & & \\
\hline & & & & & & & & & & & & & 20,54 & \\
\hline Do &, 11 & 59 & & & & & & & & & & & 3,12 & \\
\hline & & 77 & & & & & & & & & & & 16,20 & \\
\hline ra & & 3 & & & & & & & $-14,93$ & & & 1,26 & 57,94 & 45,73 \\
\hline & & & & & & & & & & & & & 6,29 & \\
\hline & & & & & & & & & & & & & 0,70 & \\
\hline & & & & & & & & & & & & & 32,66 & \\
\hline $\mathrm{Ma}$ & 06 & 35 & 3 & 9 & 2 , & & 9,63 & & 6 & & 57,96 & 96 & 17,38 & 14,32 \\
\hline & & & & & & & 90,33 & 99,40 & & & 54,08 & 36,35 & 34,09 & 36,71 \\
\hline T & & & & & & & 309,05 & 395,10 & & & 47,57 & 43,63 & 9,56 & 18,25 \\
\hline & & & & & & & & & & & & & 37,76 & \\
\hline & & & & & & & & & & & & & 5,12 & \\
\hline 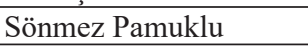 & 4,50 & 3,84 & 4,97 & & & 11,76 & 114,60 & 110,03 & 0,41 & 每 & 10,73 & 10,19 & 18,27 & 18,06 \\
\hline Vakko Tekstil & 1,55 & & 15,41 & 12,35 & & & 148,62 & 255,16 & 2,46 & & 48,30 & 40,07 & 22,83 & 29,48 \\
\hline Yataş Yatak & & & & & 5,3 & & 72,30 & & 1,40 & 1, & 41,33 & 41,33 & 16,97 & 21,27 \\
\hline Yünsa Yünlü & 3,87 & 2,10 & 4,68 & 4,31 & 5,02 & 3,76 & 98,25 & 159,31 & 2,70 & 2,27 & 66,15 & 45,85 & 6,84 & 23,57 \\
\hline
\end{tabular}


Faaliyet rasyoları incelendiğinde, işletmelerin neredeyse tamamının stok devir hızında düşüş olduğu görülmektedir. Normalde işletmelerde bazı stratejik problemlerin olduğuna da işaret edebilen bu rasyo, pandemiyle birlikte talepteki azalmanın ve sektördeki daralmanın göstergesidir. İşletmelerin \%71'inde alacak devir hızı ve \%86'sında borç devir hızları azalmıştır. İşletmelerin çoğunun borç devir hızı alacak devir hızından daha yüksektir. Uzun vadede likidite problemine yol açabilecek bu durum, 16 firmanın nakit dönüş (çevirme) süresinin uzamış olmasıyla da teyit edilmektedir. Nakit dönüş süresindeki artış, işletmelerin finansmana ihtiyaç duydukları sürenin uzadığını göstermektedir. Finansman süresindeki artış da finansman maliyetlerinde artışa neden olmakta ve kârlılığı negatif etkilemektedir. Zaten yükümlülüklerin toplam pasife oranları incelendiğinde de özellikle uzun vadeli yükümlülüklerin oranının çoğunlukla arttığı, kısa vadeli yükümlülüklerde ise bazı firmalarda azalış, bazılarında artış olduğu görülmektedir. Firmaların bir kısmı likiditelerini korumak için hem uzun hem kısa vadeli borçlanmalarını artırırken, diğer firmalar ise kısa vadeli borçlanmadan uzun vadeli borçlanmaya geçmeyi tercih etmiştir. Borçlanmalardaki artış, firmaların finansal risklerini de olumsuz etkilemektedir.

\begin{tabular}{|c|c|c|c|c|c|c|c|c|c|}
\hline & \multicolumn{2}{|c|}{$\begin{array}{l}\text { İFNA / Net } \\
\text { Kâr }\end{array}$} & \multicolumn{2}{|c|}{$\begin{array}{l}\text { İFNA / Net } \\
\text { Satışlar (\%) }\end{array}$} & \multicolumn{2}{|c|}{$\begin{array}{c}\text { İFNA / KVYK } \\
(\%)\end{array}$} & \multicolumn{3}{|c|}{ DEĞisşìM } \\
\hline & 2019 & 2020 & 2019 & 2020 & 2019 & 2020 & $\begin{array}{c}\text { İşletme } \\
\text { Faaliyetlerinden } \\
\text { Nakit Akışı (\%) }\end{array}$ & $\begin{array}{l}\text { Yatırım } \\
\text { Faaliyetlerinden } \\
\text { Nakit Akışı (\%) }\end{array}$ & \begin{tabular}{|c|} 
Finansman \\
Faaliyetlerinden \\
Nakit Akışı (\%)
\end{tabular} \\
\hline Akın Tekstil & $-0,62$ & 0,77 & $-1,75$ & 10,09 & $-4,09$ & 21,09 & 512,41 & 25,46 & $-137,64$ \\
\hline Arsan Tekstil & 0,61 & 1,21 & 12,42 & 48,83 & 22,82 & 180,54 & 270,18 & $-58,44$ & $-583,01$ \\
\hline Birko Birleşik & 0,39 & 2,15 & $-23,20$ & $-30,44$ & $-9,90$ & $-24,75$ & $-72,07$ & $-6,24$ & $1.100,05$ \\
\hline Birlik Mensucat & $-0,08$ & 0,13 & 24,87 & $-48,02$ & 1,41 & $-11,45$ & $-276,74$ & $3.653 .190,31$ & $-95,66$ \\
\hline $\begin{array}{l}\text { Bossa Ticaret ve } \\
\text { Sanayi }\end{array}$ & 0,66 & 2,27 & 6,13 & 11,99 & 11,83 & 19,43 & 98,99 & 155,95 & $-341,49$ \\
\hline Dagi Giyim & 7,86 & 0,93 & 31,36 & 6,41 & 64,89 & 8,69 & $-81,47$ & 19,40 & 93,71 \\
\hline $\begin{array}{l}\text { Derimod } \\
\text { Konfeksiyon }\end{array}$ & $-0,09$ & 1,30 & 0,19 & $-2,79$ & 0,26 & $-3,15$ & $-1.375,24$ & 2,94 & $-74,80$ \\
\hline Desa Deri & 3,46 & $-12,08$ & 14,75 & $-8,52$ & 29,28 & $-12,66$ & $-131,51$ & 50,56 & 257,79 \\
\hline $\begin{array}{l}\text { Diriteks Diriliş } \\
\text { Tekstil }\end{array}$ & 0,62 & 0,00 & $-294,81$ & 0,03 & $-71,26$ & 0,00 & 100,01 & - & - \\
\hline $\begin{array}{l}\text { Hateks Hatay } \\
\text { Tekstil }\end{array}$ & 0,65 & $-0,41$ & 8,76 & $-2,74$ & 18,82 & $-5,44$ & $-136,06$ & 15,35 & 181,85 \\
\hline Karsu Tekstil & 5,93 & 4,01 & 6,17 & 24,22 & 9,76 & 32,93 & 322,55 & $-75,54$ & $-620,26$ \\
\hline $\begin{array}{l}\text { Lüks Kadife } \\
\text { Ticaret }\end{array}$ & 1,16 & 3,63 & 13,99 & 24,63 & 46,73 & 57,22 & 92,65 & 34,42 & $-302,27$ \\
\hline Mavi Giyim & 5,59 & 48,41 & 21,07 & 16,21 & 53,71 & 21,80 & $-35,45$ & 57,98 & 152,10 \\
\hline Menderes Tekstil & $-0,55$ & 1,49 & 0,66 & $-7,51$ & 1,17 & $-14,07$ & $-1.514,96$ & $-12,82$ & 234,05 \\
\hline Rodrigo Tekstil & $-0,88$ & $-0,82$ & $-4,84$ & 5,81 & $-8,48$ & 7,03 & 192,93 & $-152,42$ & 32,06 \\
\hline Royal Halı & $-0,41$ & 0,62 & 12,16 & 2,24 & 9,39 & 1,67 & $-82,44$ & $-48,96$ & - \\
\hline Söktaş Tekstil & $-0,87$ & 0,30 & 4,10 & $-5,60$ & 4,87 & $-4,20$ & $-216,21$ & $-79,73$ & 120,80 \\
\hline Sönmez Pamuklu & 0,72 & 1,45 & 36,39 & 13,30 & 117,77 & 46,75 & $-61,00$ & 93,49 & 177,04 \\
\hline Vakko Tekstil & 2,25 & 1,67 & 14,75 & 2,28 & 34,85 & 4,37 & $-88,12$ & 38,02 & 139,48 \\
\hline $\begin{array}{l}\text { Yataş Yatak ve } \\
\text { Yorgan }\end{array}$ & 1,81 & 1,76 & 13,36 & 17,15 & 40,38 & 51,20 & 92,20 & $-32,28$ & 87,43 \\
\hline Yünsa Yünlü & 9,35 & 5,51 & 10,15 & 18,54 & 21,85 & 37,15 & 17,15 & $-49,59$ & 133,15 \\
\hline
\end{tabular}

İşletmelerin nakit akış tablolarında sundukları veriler değerlendirildiğinde, işletme faaliyetlerinden nakit akışları (IFNA) azalan 13 işletmenin bulunduğu görülmektedir. İFNA, işletmelerin ana gelir getirici faaliyetlerinden kaynaklanan nakit akışlarını temsil ettiğinden, normal şartlarda işletme faaliyetlerinden sağlanan nakit akışlarının pozitif olması beklenmektedir (Karğın ve Aktaş, 2011:4). Ancak COVID-19 pandemisiyle birlikte ekonomilerde yaşanan durgunluk ve ihracatın azalması sonucunda hasılatlardaki azalışın, nakit akışlarına da yansımış olması doğaldır.

IFNA'sı negatif olan işletmelerin yatırım ve finansman faaliyetlerinden pozitif nakit akışı sağlamaya çalışıkları, bu kapsamda bağlı ortaklık ve iştirak yatırımları da dahil olmak üzere duran varlıklarını sattıkları, özkaynağa dayalı araç ihraç ettikleri, kısa ve uzun vadeli yeni borçlanmalara girdikleri tespit edilmiştir. Alınan tedbirlerle, işletme, yatırım ve 
finansman faaliyetlerinden kaynaklanan nakit akışlarının toplamı negatif olan firma sayısı 2019 yılında $8 \mathrm{iken}, 2020$ yılında 2'ye düşmüştür. Bossa Ticaret'in 2020 yılında negatif nakit akışı yaratmış olmasının temel nedeni finansal borçlara ilişkin anapara ve faiz ödemeleridir. Derimod Konfeksiyon firmasında ise Bossa Ticaret'in aksine İFNA negatif olup, firma anapara ve faiz borç ödemelerine kıyasla daha fazla yeni borçlanma yapmış olmasına rağmen, işletme faaliyetlerinden kaynaklanan nakit çıkışlarını karşılayamamıştır.

\subsubsection{COVID-19'un Dipnot Açıklamalarına Etkileri}

COVID-19 pandemisinin işletmelerin finansal durum, performans ve nakit akışlarına etkilerinin yanında, finansal raporlarında yer alan dipnot açıklamalarında ne derece yer bulduğu ve işletmelerin COVID-19 kapsamında hangi açıklamaları yaptıkları incelenmiştir.

Birçok işletme standartlarla ilgili güncellemeler kapsamında “TFRS 16 Kiralamalar - COVID-19'la ilgili olarak tanınan kira imtiyazları" başlığıyla finansal tabloların sunumuna ilişkin esaslar kısmında COVID-19'la birlikte gelmiş olan muafiyeti açıklamıştır.

Bu güncelleme dışında raporlarında COVID-19 kelimesi hiç geçmeyen ve pandemiyle ilgili olarak hiçbir dipnot açıklaması yapmayan altı işletme (Birlik Mensucat, Dagi Giyim, Hateks Hatay Tekstil, Karsu Tekstil, Söktaş Tekstil, Sönmez Pamuklu) bulunmaktadır. Aşağıdaki tabloda COVID-19'la ilgili yapılan dipnot açıklamaları, raporda açıklamanın yapıldığı bölümlere göre özetlenerek sunulmuştur.

\begin{tabular}{|l|c|}
\hline Tablo 11: COVID-19'la İlgili Yapılan Açıklamaların Yer Aldı̆̆ı Bölümler & Firma Sayısı \\
\hline COVID-19'la İlgili Açıklama Yapılan Ana/Alt Bölümler & 3 \\
\hline Finansal Tabloları Önemli Ölçüde Etkileyen Hususlar & \\
\hline Finansal Tabloların Sunumuna İlişkin Esaslar & 5 \\
\hline Cari Döneme İlişkin Önemli Değişiklikler & 3 \\
\hline İsletmenin Sürekliliği & 1 \\
\hline Diğer Dipnot Başlıkları & 1 \\
\hline Stoklar & 1 \\
\hline Hasılat ve Satı̧̧ların Maliyeti & 1 \\
\hline Cari Döneme İlişkin Önemli Gelişmeler & 1 \\
\hline COVID-19 Etkisi & $\mathbf{1 6}$ \\
\hline Sinırlı Olumlu Görüşün Dayanağı & \\
\hline TOPLAM & \\
\hline
\end{tabular}

TFRS 16 Kiralamalar standardı ile ilgili imtiyazlar dışında COVID-19'la ilgili olarak yapılan açıklamalar en çok “Finansal Tabloların Sunumuna İlişkin Esaslar" başlığında ele alınmıştır. Birko Birleşik firması hem "Finansal Tabloları Önemli Ölçüde Etkileyen Hususlar" hem de "Stoklar” başlı̆̆ altında olmak üzere COVID-19’la ilgili olarak iki ayrı başlık altında açıklama yapan tek firmadır.

İşletmelerin yaptıkları dipnot açıklamaları içerik analizine tabi tutularak özetlenmiş ve beş ana tema altında toplanmıştır.

2020 Yllı Faaliyetleriyle Illgili Bilgilendirme: COVID-19'la ilgili olarak açıklama yapan işletmelerin çoğu pandemi nedeniyle ekonomik faaliyetlerde önemli ölçüde yavaşlama olduğu, üretim faaliyetlerinin geçici olarak duraklatıldığı, mağazaların geçici olarak kapatıldığı ve satış faaliyetlerinin online mağazalardan devam ettiği bilgilerini açıklamıştır. Genellikle Mayıs ve Haziran ayları itibariyle, alınan tedbirler kapsamında bütün faaliyetlerin yeniden başladığı konusunda açıklama yapan birkaç şirket de mevcuttur.

COVID-19 Pandemisinin Yarattı̆̆ Riskler: Çalışma kapsamında incelenen firmalardan iki tanesi işletmenin sürekliliğgi başlı̆̆ı altında salgının varlık fiyatları, likidite, kurlar ve faiz oranları gibi pek çok alanda etkilerinin olduğunu ve belirsizliklerin süreceği beklentisinin mevcut olduğunu belirtmiş̧ir. Bir firma ise yavaşlayan ekonomik aktivitelerin etkisiyle şirketin gelirlerinin düşmesinin ve nakit akışlarının etkilenmesinin muhtemel olduğunu açıklayarak, pandeminin şirket özelinde yaratabileceği risklere değinmiştir. Bir işletme de 2020 yılı denetiminde sınırlı olumlu görüş almış ve bu 
görüşün dayanağıyla ilgili denetim firmasının gerekçelerini açıklamıştır. Gerekçelerden biri olarak, salgın nedeniyle firmalar faaliyetlerini geçici süreliğine durdurmuş veya uzaktan çalışma sistemiyle faaliyetlerine devam ediyor olduklarından, ticari ve diğer alacakların ve borçların doğruluğuna yönelik olarak denetim firması tarafından yeterli mutabakat çalışması yapılamamış olmasına yer verilmiştir.

COVID-19 Kapsaminda Alınan Tedbirler ve Faydalanilan Devlet Teşvikleri: Beş işletme salgın döneminde likiditeyi güçlendirmek için nakit yönetim stratejilerini gözden geçirdiklerini ve ayrıca yatırım harcamaları, operasyonel giderler ve stoklardaki artışın minimize edilmesi için aksiyonlar alındığını açıklamıştır. Bir işletme ürün planlaması ve pazara erişim hızıyla ilgili gerekli aksiyonların alınması ve tüm satış kanallarında sürekli yeni ve güncel stok sunulabilmesinin sağlanması için gerekli önlemlerin alındığını belirtirken, diğer bir işletme de AVM'lerin kapalı olduğu dönemde AVM ve diğer mağaza kiralarının ödenmemesi veya en azından indirimli ödenmesi ve AVM ortak alan giderlerinin indirimli ödenmesi konusunda anlaşma yapıldığını belirtmiştir. Beş işletme de pandeminin olumsuz etkilerinin azaltılmasına yönelik olarak kısa çalışma ödeneğinden faydalandıkları hususuna raporlarında yer vermiştir. Bir işletme de borçlularıyla görüşerek, vadelerin ötelenmesi veya sözleşme koşullarının yeniden yapılandırılması gibi tedbirler aldığı konusunda bilgi sunmuştur.

2021 Ylliyla Ilgili Tahminler: Üç işletme bir sonraki faaliyet yılıyla ilgili olarak tahminlerini paylaşmıştır. Bir işletme gelecek bir yıl içerisinde salgının şirketin faaliyetleri üzerinde önemli bir etkisi olmasının beklenmediğini belirtirken, diğer bir işletme kısıtlamaların azalması sonucunda talepte meydana gelen artışın şirket faaliyetlerine olumlu etkisinin olacağı değerlendirmesini yapmıştır. Bir işletme de 2020 yıl sonu itibariyle kullanılmamış olan halı ipliği stoklarının, salgına bağlı olarak iplik fiyatlarındaki artış ve halı ipliği tedarik edilen firma üretimlerinin düşmesi nedeniyle satın alma sürecinde yaşanan gecikmeler doğrultusunda 2021 yılında büyük ölçüde kullanılmasını öngördüğünü açıklamıştır.

Değerleme: Sekiz işletme salgının olası etkilerinin değerlendirildiğini ancak finansal tablolarda herhangi veya önemli bir değer düşüklüğü tespit edilemediğini açıklamıştır.

Genel olarak değerlendirildiğinde, tekstil, deri ve giyim eşyası sektörlerinde faaliyet gösteren ve BİST’te listelenen şirketlerin COVID-19'la ilgili olarak ya hiç açıklama yapmadıkları ya da en fazla 2 paragraflık, çok sınırlı açıklama yaptıkları görülmektedir. Ayrıca birkaç işletmenin, denetim firmaları farklı olmasına rağmen, COVID-19'la ilgili olarak neredeyse birebir aynı açıklamaları yaptıkları görülmüştür.

Amerika'da faaliyet gösteren işletmelerin raporlarında ise COVID-19'la ilgili çok detaylı açıklamalar mevcuttur. Örneğin Ralph Lauren'in 27 Mart 2021 tarihli yıl sonu raporları incelendiğinde, COVID-19'la ilgili olarak sayfalarca açıklama yapıldığı, COVID-19'la ilgili son gelişmeler, çalışanların güvenliği ve sağlı̆̆ı, tazminatlar ve çalışanlara sağlanan faydalar, makroekonomik koşullara ilişkin riskler, stratejik girişimler ve yeniden yapılanma faaliyetlerine ilişkin riskler, iş ve faaliyetle ilgili riskler, bilgi sistemleri ve veri güvenliğine ilişkin riskler, küresel ekonomik koşullar ve sektör trendleri, finansal performansın özeti, finansal tablo kalemlerine ilişkin dipnotlar (hasılat, giderler, faaliyet bölümleri, stoklar, varlıklarda değer düşüklüğü, vb.), finansal durum ve likidite gibi başlıklar altında detaylı bilgiler sunulduğu görülmüştür. Ralph Lauren'in yıllık raporunda ve dipnotlarında COVID-19 kelimesi 146 defa yer almaktadır (https://investor.ralphlauren.com/static-files/ad83bff843c5-4092-8d25-39c97cbe384d). Guess, Inc. işletmesinin de 30 Ocak 2021 tarihli y1llık raporunda COVID-19 kelimesinin 73 defa geçtiği ve pandeminin getirdiği riskler, alınan finansal ve finansal olmayan tedbirler ve finansal tablo kalemlerine etkileri gibi birçok konunun ele alındığı belirlenmiştir. BISTT'te faaliyet gösteren işletmeler COVID-19'a ilişkin olarak finansal tablolarda herhangi/önemli bir değer düşüklüğü tespit edilemediğini açılarken, Guess firması COVID-19 pandemisinin devam eden etkileri nedeniyle varlık değer düşüklükleri ve şüpheli ticari alacaklar için daha yüksek karşılıklar yansıtıldığını açıklamıştır (https://investors.guess.com/static-files/ea4dc76d-abe1-4e4a-9d28-94c779a442d3).

Londra Borsası’nda listelenen Ted Baker Plc'nin 30 Ocak 2021 tarihli yılsonu raporunda COVID-19 kelimesi 27 defa kullanılmış ve işletmenin sürekliliği, temel riskler ve belirsizlikler, UFRS 16 standardının etkileri, finansal durumun özeti, operasyonel ve stratejik hususlar, mevcut ticari durum ve görünüm gibi başlıklarda COVID-19'un etkileri ve alınan tedbirler özetlenmiştir (https://www.tedbakerplc.com/ /media/Files/T/Ted-Baker/results-and-reports/report/2021/fy-rns-full150621.pdf). 


\section{Sonuç}

COVID-19 pandemisi, önce bir kamu sağlı̆̆1 krizi olarak başlayıp, daha sonra global finansal ve ekonomik bir krize dönüşmüştür (Cho ve Saki, 2021:1). Pandeminin kendisi kadar, seyahat kısıtlamaları, sokağa çıkma yasakları, işyerlerinin kapatılması veya belirli koşullar altında belirli saatlerde hizmet vermeleri gibi pandemiyle ilgili alınan zorunlu tedbirler de hem sosyal hem de ekonomik hayatı büyük ölçüde etkilemiştir.

Sınırlı sayıda sektör pandemiden olumlu etkilenirken, birçok sektör son derece olumsuz etkilenmiş ve işsizlik oranlarında da önemli ölçüde artış olmuştur. Bu çalışma da Türkiye’nin önde gelen sektörlerinden olan tekstil, deri ve giyim eşyası sektörlerinde faaliyet gösteren ve BİST’te listelenen işletmelerin finansal durumlarına, performanslarına ve finansal raporlarına COVID-19'un etkilerini tespit etmeyi amaçlamıştır.

Çalışma kapsamında incelenen 21 işletmenin pandemi yılında dönen ve duran varlıklarında artış olduğu, dönen varlıklardaki artışın işletmelerin nakit yönetimi stratejilerindeki değişiklik nedeniyle likiditelerini artırma çabalarından kaynaklandığı görülmektedir. Ticari alacaklardaki ve stoklardaki artış ise, faaliyet rasyolarından da görülen, alacak devir hızı ve stok devir hızındaki düşüşten kaynaklanmaktadır. Duran varlıklardaki yükselişsin nedeni ise duran varlık yatırımlarından ziyade yeniden değerleme değer artışlarıdır.

Firmaların çoğunluğunun kısa vadeli ve/veya uzun vadeli yükümlülüklerinde artış gözlemlenmiştir. Pandeminin yarattığı yoğun belirsizlik nedeniyle daha likit kalmak isteyen firmalar, borçlanma seviyelerini artırmıştır. Borçlanmalardaki artışla birlikte, özellikle de Birlik Mensucat gibi hem kısa vadeli hem de uzun vadeli yabancı kaynaklarında artış olan işletmelerin finansal risklerinin de arttığı görülmektedir.

2020 yılında işletmelerin çoğunun hasılatlarında azalış olduğu, hasılatları artan firmaların ise hazır giyimden ziyade halı, ev tekstili, yatak, yorgan, koltuk, kanepe üretimi alanlarında faaliyet gösterdikleri veya iplik, boyalı kumaş, astar gibi hazır giyim hammaddelerini üretip satan firmalar oldukları belirlenmiştir. Pandemi sürecinde tedarik zincirinde, özellikle de hammadde ithalatında yaşanan aksamalar, Türkiye'deki tekstil hammaddesi üreten firmalara olumlu yansımıştır. Hasılatlarında azalış olan firmaların yaklaşık yarısının net kar marjlarının arttı̆̆ı, ancak artışların direkt olarak pandemiyle ilişkili olmadığ ve çoğunlukla esas faaliyetlerden diğer gelirler kapsamında raporlanan unsurlardan kaynaklandığ belirlenmiştir.

2019 yılında İFNA’sı negatif olan dört işletme varken, bu sayı 2020 yılında yediye yükselmiştir. Ancak firmaların aldıkları önlemler sayesinde 2020 yılında işletme, yatırım ve finansman faaliyetlerinden nakit akışları toplamı negatif olan yalnızca iki firma olmuştur. Dolayısıyla likidite ve nakit akış yeterliliği bakımından sektör pandemi sürecinde başarılı bir sınav vermiştir.

COVID-19'un işletmelerin finansal tablo dipnotlarında yarattı̆̆ı etkiler incelendiğinde, İngiltere ve Amerika'daki halka açık işletmelere kıyasla çok az dipnot açıklaması yapıldığı görülmüştür. Altı işletme COVID-19’a ilişkin hiçbir açıklama yapmazken, diğer işletmeler de pandeminin yarattığı riskler, alınan tedbirler ve faydalanılan devlet teşvikleri, varlıklarda değer düşüklüğü gibi konularda sınırlı sayıda açıklama yapmıştır.

Genel olarak değerlendirme yapıldı̆̆ında, tekstil, deri ve giyim eşyası sektörlerinde faaliyet gösteren halka açık işletmelerin pandemi sürecini iyi yönettikleri ve birkaç işletme dışında likidite ve kârlılıkla ilgili olarak önemli sorunlar yaşanmadığ görülmüştür. Ancak pandeminin getirdiği belirsizlikler nedeniyle, işletmelerin likit kalabilmek için yabancı kaynak kullanımına daha fazla ağırlık vermelerinin yarattığı risklerin uzun vadede takip edilmesi gerekmektedir.

Ayrıca hasılatlardaki ve kârlılıktaki düşüşün de uzun vadede devam etmemesi ve işletmelerin önceki yıllardaki satış hacimlerine ulaşması için daha az insan etkileşimi içeren özelliklere sahip ürünler üretmek ve endüstrilerin tedarik zinciri sistemlerini kesintisiz olarak yönetmelerine yardımcı olacak süreçlere odaklanmak faydalı olacaktır (Equbal ve diğerleri, 2021:1). 
Bu çalışmada elde edilen bulgular Aydın ve diğerlerinin (2021) çalışmasıyla uyumludur. Mishra ve Mishra (2021), Cho ve Saki (2021) çalışmalarının aksine, Türkiye'deki halka açık tekstil, deri ve giyim eşyası işletmelerinin pandemiden önemli derecede olumsuz etkilendiğini söylemek mümkün değildir. Her ne kadar pandeminin ilk birkaç ayındaki kapanmalar ve faaliyetlerin durdurulması sonucunda ihracatta ve hasılatlarda ciddi düşüşler yaşanmışsa da Haziran 2020'den itibaren hızlı bir toparlanma sürecine girilmiş ve 2020 yılının geri kalan aylarında bir önceki yılın aynı aylarındaki ihracat rakamlarını aşan seviyeler yakalanmıştır.

$\mathrm{Bu}$ çalışmanın en önemli kısıtı, yalnızca halka açık işletmelerin ele alınmış olmasıdır. Halka açık olmayan, küçük ve orta ölçekli işletmelerin finansmana erişim imkanlarının daha sınırlı olması nedeniyle, çalışma kapsamındaki işletmeler kadar likidite sağlayamamış olmaları ve COVID-19 pandemisinden çok daha fazla etkilenmiş olmaları muhtemeldir.

Gelecek çalışmalarda COVID-19'un tekstil, deri ve giyim eşyası sektörlerine uzun vadeli etkilerinin tespit edilebilmesi için 2020'den sonraki yılların finansal verileri de kullanılarak daha detaylı analiz yapılabilir. Ayrıca farklı ülkelerden birçok işletmenin COVID-19'a ilişkin dipnot açıklamaları incelenerek, pandemi döneminde dipnot açıklamalarının kalitesini etkileyen unsurlar tespit edilebilir.

Hakem Değerlendirmesi: Dış bağımsız.

Çıkar Çatışması: Yazarlar çıkar çatışması bildirmemiştir.

Yazar Katkıları: Yazar Katkıları: Çalışma Konsepti/Tasarım- T.E., D.Ü.; Veri Toplama- T.E., D.Ü.; Veri Analizi/Yorumlama- T.E., D.Ü.; Yazı Taslağı- D.Ü., T.E.; İçeriğin Eleştirel İncelemesi- D.Ü.; Son Onay ve Sorumluluk- D.Ü., T.E.

\section{Kaynaklar}

Aydın, O., M. Oğuz, C. A. Kayalı ve H. Akay. 2021. 30. Bölüm: COVID 19 Sürecinin Tekstil, Giyim Eşyası ve Deri Sektöründeki İşletmelerin Finansal Tabloları Üzerine Etkisinin Değerlendirilmesi, Akdoğan, N., D. U. Doğan ve N. Çetinkaya (Ed.) COVID-19 Salgınının İşletmelerin Finansal Tabloları Üzerine Etkisine İlişkin Araştırma Sonuçlarının Değerlendirilmesi. Ankara: Gazi Kitabevi. Cavlak, H. 2020. “COVID-19 Pandemisinin Finansal Raporlama Üzerindeki Olası Etkileri: BİST 100 Endeksi’ndeki İşletmelerin Ara Dönem Finansal Raporlarının İncelenmesi”, Gaziantep University Journal of Social Sciences, Special Issue, 143-168.

Chen, H. ve C. Yeh. 2021 (in press). “Global financial crisis and COVID-19: Industrial reactions”, Finance Research Letters, 101940, 1-13. Cho, B. ve Z. Saki. 2021. "Firm performance under the COVID-19 pandemic: The case of the U.S. textile and apparel industry", The Journal of the Textile Institute, 1-11.

Cui, L., P. Kent, S. Kim ve S. Li. 2021 (early view). "Accounting conservatism and firm performance during the COVID-19 pandemic", Accounting \& Finance, 1-37.

Çatuk, C. ve K. Aydın. 2021. “COVID-19’un Dünya ve Türkiye Tedarik Zinciri Üzerine Etkileri”, Adıyaman Üniversitesi Sosyal Bilimler Enstitüsü Dergisi, 37, 427-449.

Dünya Gazetesi, Pandemide insanlar evde, pamuk tarlada kald1, 9 Haziran 2020, https://www.dunya.com/emtia/pandemide-insanlarevde-pamuk-tarlada-kaldi-haberi-472266 (Erişim Tarihi: 25.08.2021).

Equbal, A., S. Akhter, A. K. Sood ve I. Equbal. 2021. "The usefulness of additive manufacturing (AM) in COVID-19”, Annals of 3D Printed Medicine, 100013, 1-8.

Guess?, Inc. 30 January 2021. Annual Report, https://investors.guess.com/static-files/ea4dc76d-abe1-4e4a-9d28-94c779a442d3 (Erişim Tarihi: 10.09.2021). 
İstanbul Hazır Giyim ve Konfeksiyon İhracatçıları Birliği (İHKİB), Hazırgiyim ve Konfeksiyon Sektörü 2021 Haziran Aylık İhracat Bilgi Notu, https:/www.ihkib.org.tr/fp-icerik/ia/d/2021/07/05/hazirgiyim-ve-konfeksiyon-sektoru-2021-haziran-aylik-ihracat-bilginotu-202107051109110903-932C7.pdf (Erişim Tarihi: 10.07.2021).

İstanbul Sanayi Odas1, Türkiye'nin 500 Büyük Sanayi Kuruluşu 2020, https://www.iso500.org.tr/500-buyuk-sanayikurulusu/2020/?ara=\&sektor_tipi=NACE\&sektor_kodu=15\&oda=\&calisan_sayisi=\&sermaye_yapisi= (Erişim Tarihi: 15.07.2021).

Kamuyu Aydınlatma Platformu - Finansal Tablolar. https://www.kap.org.tr/ (Erişim Tarihi: 08.05.2021).

Kanno, M. 2021. "Assessing the impact of COVID-19 on major industries in Japan: A dynamic conditional correlation approach", Research in International Business and Finance, 58: 1-20.

Kanupriya. 2021. “COVID-19 and the Indian Textiles Sector: Issues, Challenges and Prospects”, Vision, 25(1), 7-11.

Karğın, M. ve R. Aktaş. 2011. “Türkiye Muhasebe Standartlarına Göre Raporlanmış Nakit Akış Tablosu ve Analizi”, Muhasebe ve Finansman Dergisi, 52, 1-24.

Kaur, K. 2021. “The Early Impact of COVID-19 on Textile Industry: An Empirical Analysis”, Management and Labour Studies, 1-13.

Kumar, V., S. Kumar ve Kalapna. 2021. "Impact of COVID-19 on Textile and Fashion Industry India: Economic Perspective”, Burnished Law Journal, 2(1), 312-327.

Malik, S. ve A. Khaver. 2020. Sustainable Development Policy Institute - Report, http://0-www.jstor.org.opac.bilgi.edu.tr/stable/ resrep29097 (Erişim Tarihi: 13.07.2021).

Mishra, M. ve P. Mishra. 2021. "Prioritizing Financial Crises Due to COVID-19: An Economic Safety and Sustainability Approach in India”, International Journal of System Dynamics Applications, 10(1), 65-75.

Orhan, Z. H. ve N. Tirman. 2020. "Analysis of the Impact of COVID-19 on Different Sectors in Turkey During Early Periods of the Pandemic", Journal of Business Research-Turk, 12(2), 2312-2326.

Ozili, P. ve T. Arun. 2020. Spillover of COVID-19: Impact on the Global Economy. https://papers.ssrn.com/sol3/papers.cfm?abstract_ id=3562570 (Erişim Tarihi: 24.07.2021).

Ralph Lauren Corporation. 27 March 2021. Annual Report, https://investor.ralphlauren.com/static-files/ad83bff8-43c5-4092-8d2539c97cbe384d (Erişim Tarihi: 10.09.2021).

Szczygielski, J. J., A. Charteris, P. R. Bwanya ve J. Brzeszczynski. 2021 (in press). "The impact and role of COVID-19 uncertainty: A global industry analysis", International Review of Financial Analysis, 1-54.

Ted Baker Plc. 30 January 2021. Annual Report, https://www.tedbakerplc.com/ /media/Files/T/Ted-Baker/results-and-reports/ report/2021/fy-rns-full150621.pdf (Erişim Tarihi: 10.09.2021).

Türkiye Cumhuriyeti Ticaret Bakanlığı İhracat Genel Müdürlüğü. 2020. Hazır Giyim Sektör Raporu, https://ticaret.gov.tr/ data/5b87000813b8761450e18d7b/Haz\%C4\%B1r\%20Giyim\%20Sekt\%C3\%B6r\%C3\%BC_2018.pdf (Erişim Tarihi: 14.07.2021).

Uyanık, S. ve D. C. Çelikel. 2019. “Türk Tekstil Endüstrisi Genel Durumu”, Teknik Bilimleri Dergisi, 9(1), 32-41.

Üçoğlu, D. 2021. Chapter 3: Financial Impacts of COVID-19 on Tourism: Evidence from Some Listed Companies, Demir, M., A. Dalgıç ve F. Doğanay Ergen (Ed.) Handbook of Research on the Impacts and Implications of COVID-19 on the Tourism Industry. USA: IGI Global. 